\title{
Sensitivity of Rhizoctonia Isolates to Phenazine-1-Carboxylic Acid and Biological Control by Phenazine-Producing Pseudomonas spp.
}

\author{
Ahmad Kamil Mohd Jaaffar, James A. Parejko, Timothy C. Paulitz, David M. Weller, and Linda S. Thomashow
}

First and second authors: Department of Plant Pathology, Washington State University, Pullman 99164-6430; and third, fourth, and fifth authors: United States Department of Agriculture-Agricultural Research Service, Wheat Health, Genetics and Quality Research Unit, Pullman, WA 99164-6430.

Current address of A. K. M. Jaaffar: Malaysian Cocoa Board, Biotechnology Park, 94300 Kota Samarahan, Sarawak, Malaysia. Current address of J. A. Parejko: Gustavus Adolphus College, 800 West College Avenue, St. Peter, MN 56082.

Accepted for publication 6 February 2017.

\begin{abstract}
Rhizoctonia solani anastomosis groups (AG)-8 and AG-2-1 and R. oryzae are ubiquitous in cereal-based cropping systems of the Columbia Plateau of the Inland Pacific Northwest and commonly infect wheat. AG-8 and $R$. oryzae, causal agents of Rhizoctonia root rot and bare patch, are most commonly found in fields in the low-precipitation zone, whereas $R$. solani AG-2-1 is much less virulent on wheat and is distributed in fields throughout the low-, intermediate-, and high-precipitation zones. Fluorescent Pseudomonas spp. that produce the antibiotic phenazine-1-carboxylic acid (PCA) also are abundant in the rhizosphere of crops grown in the lowprecipitation zone but their broader geographic distribution and effect on populations of Rhizoctonia is unknown. To address these questions, we surveyed the distribution of PCA producers $\left(\mathrm{Phz}^{+}\right)$in 59 fields in cerealbased cropping systems throughout the Columbia Plateau. $\mathrm{Phz}^{+}$Pseudomonas spp. were detected in 37 of 59 samples and comprised from 0 to $12.5 \%$ of the total culturable heterotrophic aerobic rhizosphere bacteria. The frequency with which individual plants were colonized by $\mathrm{Phz}^{+}$

located in the driest areas whereas only moderate and low colonization frequencies were associated with crops where higher annual precipitation occurs. Thus, the geographic distribution of $\mathrm{Phz}^{+}$pseudomonads overlaps closely with the distribution of $R$. solani AG- 8 but not with that of $R$. oryzae or $R$. solani AG-2-1. Moreover, linear regression analysis demonstrated a highly significant inverse relationship between annual precipitation and the frequency of rhizospheres colonized by $\mathrm{Phz}^{+}$ pseudomonads. $\mathrm{Phz}^{+}$pseudomonads representative of the four major indigenous species ( $P$. aridus, $P$. cerealis, $P$. orientalis, and $P$. synxantha) suppressed Rhizoctonia root rot of wheat when applied as seed treatments. In vitro, mean 50\% effective dose values for isolates of AG-8 and AG-2-1 from fields with high and low frequencies of phenazine producers did not differ significantly, nor was there a correlation between virulence of an isolate and sensitivity to PCA, resulting in rejection of the hypothesis that tolerance in Rhizoctonia spp. to PCA develops in nature upon exposure to $\mathrm{Phz}^{+}$pseudomonads.
\end{abstract} pseudomonads ranged from 0 to $100 \%$. High and moderate colonization frequencies of $\mathrm{Phz}^{+}$pseudomonads were associated with roots from fields
Additional keyword: barley.
Wheat (Triticum aestivum L.) is grown throughout the Pacific Northwest (PNW) in the United States, an area east of the Cascade Mountains of some $62,160 \mathrm{~km}^{2}$ divided into three annual precipitation zones: low ( $<300 \mathrm{~mm}$ precipitation), intermediate (300$450 \mathrm{~mm}$ ), and high (450 to $600 \mathrm{~mm}$ ) (Schillinger et al. 2008). In the low-precipitation zone, directly east of the mountains and within their rain shadow, wheat has been grown for over 125 years under dryland conditions in an alternate winter wheat-summer fallow rotation (Schillinger and Papendick 2008). During the year of fallow, water accumulates in the soil profile to support a wheat crop the following year. Precipitation increases significantly with increasing distance to the east of the low-precipitation zone. In the easternmost part of Washington (high-precipitation zone known as the Palouse), winter wheat is often grown in a 3-year rotation with spring wheat or spring barley (Hordeum vulgare L.) and lentil (Lens culinaris Medik.), pea (Pisum sativum L.), chickpea (Cicer arietinum L.), or canola (Brassica napus L.). In the intermediate zone, cropping practices

Corresponding authors: L. S. Thomashow; E-mail addresses: linda.thomashow@ ars.usda.gov and thomashow@wsu.edu; and D. M. Weller; E-mail addresses: david. weller@ars.usda.gov and wellerd@wsu.edu

*The $e$-Xtra logo stands for "electronic extra" and indicates that three supplementary figures are published online.

This article is in the public domain and not copyrightable. It may be freely reprinted with customary crediting of the source. The American Phytopathological Society, 2017. transition and a winter wheat-spring wheat or barley-summer fallow rotation is often used.

A wide variety of soilborne fungal pathogens occur in cereal-based production systems throughout the Columbia Plateau of the Inland PNW. Four of the most important soilborne fungal diseases of cereals are Rhizoctonia root rot and bare patch caused by Rhizoctonia solani Kühn anastomosis group (AG)-8 and $R$. oryzae Ryker \& Gooch (Paulitz et al. 2002; Weller et al. 1986); take-all caused by Gaeumannomyces graminis var. tritici J. Walker (Paulitz et al. 2002; Weller et al. 2007); Pythium root rot caused by a complex of Pythium spp., with Pythium irregulare groups I and IV and P. ultimum being the two most pathogenic species (Higginbotham et al. 2004; Paulitz and Adams 2003); and crown and root rot caused by Fusarium pseudograminearum, F. culmorum, and Bipolaris sorokiniana (Paulitz et al. 2002, 2009). The severity of take-all, Rhizoctonia root rot and bare patch, and Pythium root rot is exacerbated by reduced tillage (Paulitz et al. 2002), and Rhizoctonia root rot has become the most important disease in no-till (direct-seeded) cereal production. $R$. solani AG-2-1, the dominant Rhizoctonia sp. across the region, causes only mild root rot of cereals but is an important pathogen of canola, a rotation crop (Jaaffar et al. 2016; Paulitz et al. 2006).

$R$. solani AG-8 and $R$. oryzae are ubiquitous in wheat fields throughout the Columbia Plateau of the Inland PNW, yet the severity of root rot and bare patch differs throughout the region. Root rot is most severe in the low-precipitation zone (150 to $300 \mathrm{~mm}$ ) when wheat is grown with reduced tillage and, under these conditions, classic "bare patches" appear in the field (Paulitz et al. 2009; 
Schillinger and Paulitz 2006). Patches may vary in size from only a few centimeters to tens of meters in diameter, and sometimes an entire field becomes a single patch. In contrast, in the highprecipitation zones such as the Palouse, patches rarely occur and Rhizoctonia root rot generally appears as unevenness in plant height throughout the field (Paulitz et al. 2002, 2009).

Mavrodi et al. (2012a) reported that large populations (greater than $10^{5} \mathrm{CFU} \mathrm{g}-1$ of root) of fluorescent Pseudomonas spp. producing the broad-spectrum antibiotic phenazine-1-carboxylic acid (PCA) colonized the roots and rhizosphere of wheat and barley grown in dryland (nonirrigated) fields in the low-precipitation zone. In addition, they found that the frequency of root systems colonized by PCA-producing $\left(\mathrm{Phz}^{+}\right)$pseudomonads was inversely related to annual precipitation but not to differences in soil temperature or composition (O. Mavrodi, D. Mavrodi, A. Panchenko, K. Cooper, D. Weller, and L. Thomashow, unpublished data), suggesting that these bacteria thrive in dry soils. PCA also was detected at nanomolar concentrations in the rhizosphere and there was a direct relationship between the amount of PCA extracted from the roots and the population density of $\mathrm{Phz}^{+}$Pseudomonas spp. The Pseudomonas populations included at least 31 genotypes that clustered as Pseudomonas synxantha, $P$. orientalis, and the provisional species $P$. aridus and $P$. cerealis of the $P$. fluorescens complex, all of which carried the phenazine biosynthesis gene $p h z F$ and synthesized PCA (Parejko et al. 2012, 2013). $\mathrm{Phz}^{+}$pseudomonads were highly inhibitory to $R$. solani AG-8 in vitro, suggesting that they might contribute to the protection of wheat and barley against Rhizoctonia root rot (Mavrodi et al. 2012a,b).

The role of phenazines in biocontrol of plant pathogens was first reported by Thomashow and Weller (1988), who demonstrated that mutants of $P$. synxantha (formerly $P$. fluorescens) 2-79 deficient in PCA synthesis were less suppressive of take-all of wheat than the parental strain. Pierson and Thomashow (1992) then showed that phenazine-deficient mutants of $P$. chlororaphis 30-84 also lost the ability to suppress take-all. Thomashow et al. (1990) recovered phenazines from the roots of wheat seedlings colonized by strains 2-79 or 30-84 but not from roots colonized by the phenazine-deficient mutants. Since those classic studies, there have been numerous reports of introduced phenazine-producing Pseudomonas spp. providing biocontrol of diverse soilborne pathogens (Chin-A-Woeng et al. 2003; Mavrodi et al. 2006; Pierson and Pierson 2010). However, few studies have evaluated the effectiveness of phenazine producers in the biocontrol of Rhizoctonia spp. For example D'aes et al. (2011) tested Pseudomonas strain CMR12a, which produces PCA and phenazine1-carboxamide as well as cyclic lipopeptide (CLP) surfactants, for ability to suppress AG-2-2 and AG-4 HGI on bean. Mutants deficient in either phenazine or CLP production provided significantly less control of Rhizoctonia root rot than did the parental strain. A double mutant deficient in production of both compounds completely lost biocontrol activity, indicating that the CLP and phenazines function together in the control of Rhizoctonia spp. (D'aes et al. 2011).
Phenazine-producing Pseudomonas spp. with biocontrol activity have been isolated from numerous crops worldwide (Chin-A-Woeng et al. 2003; Mavrodi et al. 2006, 2010; Yang et al. 2011) and they also contribute to the suppressiveness of the soils in the Châteaurenard region of France to Fusarium wilt by working in concert with nonpathogenic F. oxysporum (Mazurier et al. 2009).

The current study is part of a broader project with the overarching goal of filling gaps in our knowledge about the biogeography of $\mathrm{Phz}^{+}$fluorescent Pseudomonas spp. in the Inland PNW; the role of these pseudomonads in the health, productivity, and sustainability of dryland wheat; and their impact on soilborne pathogens and rhizosphere microbial communities in dryland cereal-based cropping systems. We hypothesize that $\mathrm{Phz}^{+}$pseudomonads have a broader role in the control of Rhizoctonia spp. across the Columbia Plateau than previously recognized. Here, we have used classical and molecular approaches to assess the biogeographic overlap of PCA producers and Rhizoctonia spp. throughout the Columbia Plateau of the Inland PNW to determine whether long-term exposure of Rhizoctonia isolates to $\mathrm{Phz}^{+}$fluorescent Pseudomonas spp. in the field reduces the sensitivity in Rhizoctonia spp. to PCA, and to evaluate the biocontrol activity against $R$. solani AG- 8 of various species of $\mathrm{Phz}^{+}$Pseudomonas spp. known to exist in cereal-based production systems. We show that, in the Columbia Plateau, the geographic distribution of PCA producers closely overlaps with that of AG-8 isolates, that Rhizoctonia AG and species differ in sensitivity to PCA, and that various genotypes of PCA producers found in cereal-based cropping systems are able to suppress Rhizoctonia root rot.

\section{MATERIALS AND METHODS}

Bacteria, fungi, and culture conditions. Rhizoctonia isolates for this study were collected in the summers of 2010 (117 isolates) and 2011 (180 isolates) by using the toothpick assay of Paulitz and Schroeder (2005), as described previously (Jaaffar et al. 2016). Phenazine-producing $\left(\mathrm{Phz}^{+}\right)$pseudomonads collected during the field surveys in 2010, as well as previously described strains used in the fungal inhibition analyses and representative of the $\mathrm{Phz}^{+}$species P. cerealis, $P$. aridus, $P$. orientalis, and $P$. synxantha (Parejko et al. 2013) (Table 1), were cultured on King's medium B (KMB) broth or agar (King et al. 1954) at $27^{\circ} \mathrm{C}$ and stored in $40 \%$ glycerol at $-80^{\circ} \mathrm{C}$.

Field sampling. Fields in cereal-based cropping systems in the Inland PNW were surveyed for pseudomonads containing biosynthesis genes for PCA and the capacity to produce phenazine antibiotics. The survey included 59 sites that consisted of commercial fields and Washington State University Cooperative Extension Uniform Cereal Cultivar Testing sites located within the low (150 to $300 \mathrm{~mm}$ ), intermediate ( 300 to $450 \mathrm{~mm}$ ), and high $(>450 \mathrm{~mm}$ ) precipitation zones (Jaaffar et al. 2016) that were sampled from mid-May through mid-July 2010. In addition to winter wheat and spring wheat, samples of spring

TABLE 1 . Bacterial strains used in this study

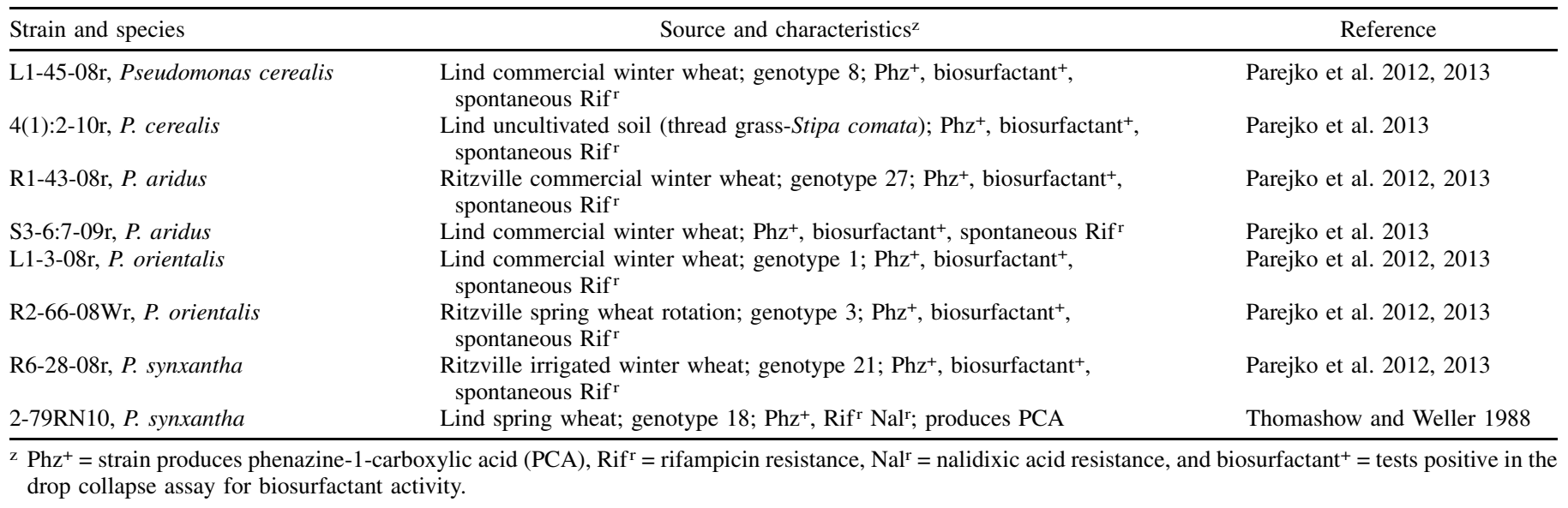


barley, spring pea, spring chick pea, and spring lentil also were collected. Longitudinal and latitudinal coordinates at each site were recorded using a Garmin global positioning system (GPS) device. At each location, three samples consisting of plants with adhering rhizosphere soil were dug with a shovel to a depth of approximately $20 \mathrm{~cm}$. The first sample was taken approximately $100 \mathrm{~m}$ into the field and two additional samples were collected $25 \mathrm{~m}$ further into the field in a zig-zag pattern. Each sample in a field served as a replicate and was placed in a separate labeled plastic bag, transported to the laboratory, and stored at $4{ }^{\circ} \mathrm{C}$ overnight for processing the next day.

From each replicate bag, four plants were assayed separately to determine the population sizes of total culturable heterotrophic aerobic bacteria and $\mathrm{Phz}^{+}$pseudomonads, and the frequency with which individual root systems were colonized by $\mathrm{Phz}^{+}$pseudomonads.

Enumeration of $\mathbf{P h z}^{+}$and total culturable aerobic bacteria. Bacteria were isolated from the roots of individual plants essentially as described by Mavrodi et al. (2012b). Briefly, each root system with adhering rhizosphere soil was placed in a 50-ml screw-cap centrifuge tube with $20 \mathrm{ml}$ of sterile distilled water. The samples were vortexed vigorously (1 min) and sonicated $(1 \mathrm{~min})$ in an ultrasonic cleaner (Bransonic 521; Branson, Shelton, CT), and bacterial population sizes were determined using the dilution endpoint assay (McSpadden Gardener et al. 2001). An aliquot (100 $\mu \mathrm{l})$ of the root wash solution was serially diluted (1:3) in a 96-well microtiter plate prefilled with $200 \mu \mathrm{l}$ of sterile water, and $50 \mu \mathrm{l}$ of each dilution was transferred to wells of two other microtiter plates containing (i) a semiselective medium for fluorescent Pseudomonas spp. consisting of one-thirdstrength KMB supplemented with cycloheximide $(100 \mu \mathrm{g} / \mathrm{ml})$, ampicillin $(25 \mu \mathrm{g} / \mathrm{ml})$, and chloramphenicol $(13 \mu \mathrm{g} / \mathrm{ml})\left(1 / 3 \mathrm{KMB}^{++}\right)$; and (ii) one-tenth-strength tryptic soy broth (1/10 TSB) (BD Biosciences, Franklin Lakes, NJ) supplemented with cycloheximide $(100 \mu \mathrm{g} / \mathrm{ml})$ $\left(1 / 10 \mathrm{TSB}^{+}\right)$. These plates were incubated at room temperature $\left(24 \pm 1^{\circ} \mathrm{C}\right)$ in the dark for $72 \mathrm{~h}$ and then turbidity was assessed spectrophotometrically with a Bio-Rad model 680 microplate reader (Bio-Rad, Hercules, CA). An optical density at $600 \mathrm{~nm}$ $\left(\mathrm{OD}_{600}\right)>0.1$ was scored as positive for bacterial growth (Mavrodi et al. 2012b; McSpadden Gardener et al. 2001).

Each dilution well with growth in $1 / 3 \mathrm{KMB}^{+++}$was screened for the presence of $\mathrm{Phz}^{+}$bacteria by polymerase chain reaction (PCR) with primers targeting the biosynthesis gene $p h z F$ (primers Ps_up1 and Ps_low1) (Mavrodi et al. 2010). Strains carrying this marker routinely produce PCA in culture (Parejko et al. 2012). Population densities of $\mathrm{Phz}^{+}$pseudomonads were calculated from the final dilution in which a $p h z F$ signal appeared. The final dilution in which bacterial growth occurred in $1 / 10 \mathrm{TSB}^{+}$was used to calculate the population size of total culturable heterotrophic aerobic bacteria.

Effect of pH on the growth of Rhizoctonia isolates. In preparation for assessing their sensitivity to PCA, Rhizoctonia isolates were first tested to determine the optimum $\mathrm{pH}$ for growth in vitro. Two isolates each of $R$. solani groups AG-8, AG-2-1, AG-10, and AG-I-like binucleate Rhizoctonia sp. and two isolates each of $R$. oryzae groups II and III were selected for these studies. Growth medium (one-fifth potato dextrose agar [1/5 PDA]) was buffered to six $\mathrm{pH}$ values ranging from $\mathrm{pH} 5.4$ to $\mathrm{pH} 7.6(\mathrm{pH} 5.4,6.0,6.4,6.8$, 7.2, and 7.6) with $0.2 \mathrm{M}$ phosphate buffer $\left(\mathrm{Na}_{2} \mathrm{HPO}_{4}\right.$ and $\left.\mathrm{KH}_{2} \mathrm{PO}_{4}\right)$. This range of $\mathrm{pH}$ values was chosen because of a previous report by Sherwood (1970), who indicated that isolates of Rhizoctonia grew best between $\mathrm{pH} 5$ and $\mathrm{pH}$ 7. Agar plugs (4 $\mathrm{mm}$ in diameter) were cut with a cork borer from the advancing margin of a 7-day-old culture of an isolate of Rhizoctonia grown on 1/5 PDA. The agar plugs were transferred with the mycelium facing down to the center of Petri dishes containing 1/5 PDA adjusted to the various $\mathrm{pH}$ values. Three plates were used per treatment and each plate served as a replicate. Radial growth on each plate was measured in four different directions from the edge of the plug to the edge of the mycelium every $12 \mathrm{~h}$ after inoculation for 5 days. The rate of growth, expressed as millimeters per day, was calculated based on radial growth at $120 \mathrm{~h}$ minus radial growth at $48 \mathrm{~h}$ divided by 3 days.
Sensitivity to PCA in vitro. Selected isolates of $R$. solani AG-8, AG-2-1, and AG-10; AG-I-like binucleate Rhizoctonia; and $R$. oryzae groups I, II, and III were tested for sensitivity to PCA in agar plate bioassays. In addition, in a separate experiment, 20 isolates each of $R$. solani AG-8 and AG-2-1 collected from regions where cereal roots are normally colonized by either low or high frequencies of PCA producers were tested in the plate bioassay to determine whether tolerance or resistance to PCA can develop in the field. For each assay, 4-mm-diameter agar plugs were cut with a cork borer from the margin of a 1-week-old culture of Rhizoctonia spp. grown on 1/5 PDA. The agar plugs were transferred with the mycelium facing downward to the center of 36-mm-diameter wells containing $5 \mathrm{ml}$ of $1 / 5 \mathrm{PDA}$ buffered to $\mathrm{pH} 6.0$ with $0.01 \mathrm{M} 2-(\mathrm{N}-$ morpholino)ethanesulfonic acid (MES) (Sigma Aldrich, St. Louis) in a six-well tissue culture plate (Becton Dickinson Labware, Franklin Lakes, NJ). MES buffer was used to avoid possible effects on growth of the ionic strength of $0.2 \mathrm{M}$ phosphate buffer. Wells in each plate were amended with PCA dissolved in ethyl acetate at 0,3 , $5,10,20$, and $40 \mu \mathrm{g} / \mathrm{ml}$. Mycelial growth was measured every $12 \mathrm{~h}$ after inoculation from the center of the plug to the edge of the mycelium. Each six-well plate (block) was replicated three times, and each measurement was performed in four different directions per well. Radial growth measurements were converted to percent growth inhibition by comparing growth on medium amended with PCA to that on medium with no PCA (control, ethyl acetate only). Growth measurements at $72 \mathrm{~h}$ provided the greatest difference between the control and PCA treatments and, thus, were used for the final analysis of growth inhibition. Growth inhibition data were transformed to a linear regression versus PCA concentration. Points from three replicate plates were pooled (18 points: three replicates $\times$ six dosages) to run the regression. The $50 \%$ effective dose $\left(E_{50}\right)$ values were calculated from the predicted regression equation.

Determination of virulence and pathogenicity. Twenty selected isolates each of $R$. solani AG- 8 and AG-2-1 collected from fields with high or low frequencies of $\mathrm{Phz}^{+}$rhizobacteria were tested for pathogenicity and virulence on wheat (T. aestivum 'Louise') by using a modification of the tube assay previously described by Jaaffar et al. (2016). Briefly, the assays were conducted in conical plastic tubes (cone-tainers, $2.5 \mathrm{~cm}$ wide at the top by $16.5 \mathrm{~cm}$ in height; Stewe and Sons, Tangent, OR) plugged with a cotton ball and hung in plastic racks (200 tubes/rack). Each tube was filled with a $10-\mathrm{cm}$ column of sterilized vermiculite and then a 2-cm-layer of Quincy virgin (Shano sandy loam) pasteurized soil $\left(60^{\circ} \mathrm{C}, 30 \mathrm{~min}\right.$.). Three plugs ( $5 \mathrm{~mm}$ in diameter) cut from a plate of PDA colonized by a fungal isolate were added to the top of the soil layer and then covered with a 1-cm layer of vermiculite. Controls consisted of tubes with plugs of PDA without mycelium. Three spring wheat seeds (Louise) were placed on the vermiculite and covered with another 1-cm layer of vermiculite. Each tube received $10 \mathrm{ml}$ of water containing metalaxyl (wettable powder at $0.075 \mathrm{~g} \mathrm{liter}^{-1}$ of tap water) (Syngenta, Wilmington, DE) to suppress indigenous Pythium spp. that can cause damping-off and interfere with the disease ratings. Each replicate of a treatment (isolate) consisted of five separate tubes; treatments were replicated three times and arranged in a randomized complete block design. The racks of tubes were covered with transparent plastic and incubated at $24^{\circ} \mathrm{C}$ for 2 days before being moved into a growth room at $16^{\circ} \mathrm{C}$ with a $12-\mathrm{h}$ photoperiod (Jaaffar et al. 2016). After emergence, the plastic was removed and plants were irrigated twice a week with $12 \mathrm{ml}$ of water and once with one-third-strength Hoagland's solution (macroelements only) (Jaaffar et al. 2016). Four weeks after planting, seedlings were removed and washed under a stream of water. To determine the impact of an isolate on plant growth, shoot length was measured and root disease severity was rated on a scale of 0 to 8 (Huang et al. 2004), where $0=$ healthy or uninfected (disease not evident) and $8=$ plant dead or nearly so. This scale considers both root disease and the health of the foliage. 
Preparation of oat kernel inoculum. Inoculum of $R$. solani AG-8 strain C-1 used in biocontrol assays was prepared essentially as described by Kwak et al. (2009). Briefly, $250 \mathrm{ml}$ of whole oat grains and $300 \mathrm{ml}$ of water were mixed in a 1-liter Erlenmeyer flask and autoclaved for $90 \mathrm{~min}$ on two consecutive days. Small pieces of agar cut from a 7-day-old culture of $R$. solani AG-8 isolate C-1 were added and the flasks were then incubated for 3 to 4 weeks at room temperature. Colonized oat kernels were dried for 2 days under a stream of sterile air and stored at $4{ }^{\circ} \mathrm{C}$.

Bacterial treatment of wheat seed. For biological control studies, bacterial strains were grown on $\mathrm{KMB}$ for $48 \mathrm{~h}$ at $27^{\circ} \mathrm{C}$. Two to three loopfuls of each isolate were suspended in $1.0 \mathrm{ml}$ of sterile water and washed twice by centrifugation for $3 \mathrm{~min}$ at $14,000 \mathrm{rpm}$ in an Eppendorf centrifuge, and the suspension was adjusted to an $\mathrm{OD}_{600}$ of 1. For each $4.68 \mathrm{~g}$ of seed, $173 \mu \mathrm{l}$ of the bacterial suspension, $107 \mu \mathrm{l}$ of water, and $280 \mu \mathrm{l}$ of sterile $2 \%$ methylcellulose (MC) (Sigma-Aldrich) were mixed in a test tube, vortexed for $30 \mathrm{~s}$, shaken by hand for $3 \mathrm{~min}$, and then dried under sterile air in a laminar flow hood for at least an hour. Once dry, the inoculated seed were stored at $4^{\circ} \mathrm{C}$ until sown. The final density of the bacteria was approximately $10^{7} \mathrm{CFU}$ seed ${ }^{-1}$.

Rhizoctonia root rot suppression assay. A modification of the tube assay described above was used to determine the biocontrol activity of $\mathrm{Phz}^{+}$bacteria against $R$. solani. Each tube was filled with a $10-\mathrm{cm}$ column of sterilized vermiculite topped with a 2-cm-layer of air-dried and sieved pasteurized or nontreated Quincy virgin soil (Shano sandy loam). The soil was mixed with $0.7 \%$ (wt/wt) oat kernel inoculum of $R$. solani AG-8 strain C-1 that had been ground and sieved to obtain particle sizes of 0.25 to $0.5 \mathrm{~mm}$. Three wheat seeds (Louise) coated with $\mathrm{Phz}^{+}$wild-type bacteria in $1 \% \mathrm{MC}$ were placed on the soil surface and covered with a 2-cm-thick layer of sterilized vermiculite. Controls consisted of tubes (i) with pathogen inoculum plus seed coated with $1 \% \mathrm{MC}$ and (ii) with pathogen inoculum plus noncoated seed. There were five tubes per treatment and each treatment was replicated five times. Treatments were arranged in a randomized complete block design. The tubes were watered and incubated and disease was evaluated as described above.

Statistical analysis. To plot the geographic distribution and frequency of phenazine-producing Pseudomonas spp., maps were constructed with GPS coordinates of sampled fields by using ArcGIS 9.3.1 software (ESRI, Redlands, CA). Data from biological control experiments were analyzed by using STATISTIX 8.0 software (Analytical Software, St. Paul, MN). Bacterial population data were converted to $\log \mathrm{CFU} \mathrm{g}{ }^{-1}$ fresh weight of root. Differences in root disease (disease ratings) and plant height among treatments were determined by standard analysis of variance and mean comparisons among treatments were performed by using Fisher's protected least significant difference test $(P=0.05)$ or by the Kruskal-Wallis test $(P=0.05)$.

\section{RESULTS}

Population size and colonization frequency of $\mathbf{P h z}^{+}$Pseudomonas spp. in the rhizosphere of dryland crops. $\mathrm{Phz}^{+}$Pseudomonas spp. were detected in 37 of 59 samples of winter and spring wheat and spring barley collected from 59 fields in 2010 (Table 2). Population sizes ranged from below the limit of detection $(\log 3.2$ $\mathrm{CFU} \mathrm{g}{ }^{-1}$ ) to $\log 7.4 \mathrm{CFU} \mathrm{g}^{-1}$ (fresh weight) of roots. Population sizes of total culturable heterotrophic aerobic bacteria in all 59 samples ranged from $\log 7.4$ to $\log 8.9 \mathrm{CFU} \mathrm{g}^{-1}$ (fresh weight) of root (Table 2). $\mathrm{Phz}^{+}$pseudomonads comprised from 0 to $12.5 \%$ of the total culturable heterotrophic aerobic bacteria present in the rhizosphere microbiome.

The frequency with which individual plants within a sample were colonized by $\mathrm{Phz}^{+}$pseudomonads ranged from 0 to $100 \%$ (Table 2). To simplify visualization of the distribution of $\mathrm{Phz}^{+}$pseudomonads in the Columbia Plateau of the Inland PNW, colonization frequencies were combined into three frequency groups: low (0 to 0.32 ), medium (0.33 to 0.66 ), and high (0.67 to 1$)$. High and medium colonization frequencies were associated with wheat or barley roots from fields located in the driest areas of the Columbia Plateau (agronomic zones 4 and 5) (Fig. 1). In our study, $\mathrm{Phz}^{+}$pseudomonads were not sampled from cereals grown in agronomic zone 6 (Fig. 1) but they are known to be present in high frequencies on wheat grown there (Mavrodi et al. 2012a). In contrast, only moderate and low colonization frequencies of $\mathrm{Phz}^{+}$pseudomonads were associated with cereals in agronomic zones 1, 2, and 3, where higher annual precipitation occurs (Fig. 1). Linear regression analysis (Fig. 2) demonstrated a low but highly significant $\left(r^{2}=0.38, P=0.005\right)$ inverse relationship between annual precipitation (averaged for the sampled sites for the 30-year period from 1971 to 2000) and the frequency of rhizospheres of plants colonized by $\mathrm{Phz}^{+}$pseudomonads.

Samples of pea $(n=5)$, lentil $(n=3)$, and chickpea $(n=2)$ collected from 10 separate fields in agronomic zones 1 and 2 all had low frequencies of $\mathrm{Phz}^{+}$pseudomonads; in fact, all samples but two had no detectable colonization (Table 2).

Spatial relationship between $\mathbf{P h z}^{+}$pseudomonads and R. solani AG-8 and 2-1. $R$. solani AG-8 is cosmopolitan in the Columbia Plateau but is most frequently isolated from fields located in arid areas (Jaaffar et al. 2016; Okubara et al. 2014). Figure 1, originally published in Jaaffar et al. (2016), has been modified here to show the overlap of the frequency (low, moderate, and high) of rhizospheres colonized by $\mathrm{PCA}^{+}$pseudomonads and the number of AG-8 isolates in a given agronomic zone. The highest frequencies of $\mathrm{Phz}^{+}$pseudomonads occurred in areas where AG- 8 isolates also were most frequently isolated (agronomic zones 4 and 5). In agronomic zones 1, 2, and 3, both $\mathrm{Phz}^{+}$pseudomonads and AG-8 isolates were isolated much less often. Similarly, Figure 3, also from Jaaffar et al. (2016), shows the overlap in frequency (low, moderate, and high) of rhizospheres colonized by $\mathrm{PCA}^{+}$pseudomonads and AG-2-1isolates in a given agronomic zone. In contrast to AG-8 isolates, AG-2-1 isolates did not overlap with $\mathrm{Phz}^{+}$pseudomonads. AG-2-1 isolates are more evenly distributed throughout the Columbia Plateau of the Inland PNW compared with AG-8 isolates (Jaaffar et al. 2016).

Effect of pH on growth in vitro of Rhizoctonia AG and species. As a prelude to determining the sensitivity of Rhizoctonia $\mathrm{AG}$ and species to PCA, the $\mathrm{pH}$ at which growth is optimal was first determined in 1/5 PDA buffered to different $\mathrm{pH}$ values. The growth rate of the various Rhizoctonia isolates, expressed in millimeters per day, was modulated by the $\mathrm{pH}$ of the medium (Table 3; Supplementary Fig. S1). Among the isolates of AG-8, AG-2-1, AG-10, AG-I-like binucleate, and $R$. oryzae groups II and III, AG-10 had the fastest growth rate at $\mathrm{pH}$ values of 5.4 to 6.4 but AG-I-like binucleate Rhizoctonia sp. had the fastest rate among the isolates at $\mathrm{pH} 7.2$ to 7.6. $R$. oryzae group III had the slowest growth rate of all isolates at all $\mathrm{pH}$ levels tested (Table 3). In general, all Rhizoctonia isolates grew at a slower rate at pH 6.4 and above as compared with at pH 5.4 and 6.0. Especially striking was the difference in growth of the isolates of $R$. oryzae groups II and III. On this basis, $\mathrm{pH} 6$ was selected for studies of the in vitro inhibition of Rhizoctonia isolates by PCA.

Sensitivity of Rhizoctonia isolates to PCA. Isolates of AG-8, AG-2-1, AG-10, AG-I-like binucleate, and $R$. oryzae groups I, II, and III were tested for their sensitivity to PCA in PDA buffered to $\mathrm{pH}$ 6.0. $\mathrm{ED}_{50}$ values varied among Rhizoctonia isolates (5 to $20 \mu \mathrm{g} / \mathrm{ml}$ ), and isolates of different AG showed differential sensitivity to PCA. For example, AG-8 isolates were least sensitive to PCA but were not significantly different in their sensitivity from isolates of AG-2-1 and $R$. oryzae groups II and III. AG- 8 isolates were significantly less sensitive to PCA than isolates of AG-10, AG-I-like binucleate Rhizoctonia sp., and $R$. oryzae group I. $R$. oryzae group II isolates were significantly less sensitive to PCA than group I isolates (Table 4). It is well known that long-term exposure of human, animal, or plant pathogens to antibiotics or fungicides can result in the development of resistance to the compound in their populations. We tested the hypothesis that tolerance to naturally occurring antibiotics can occur in nature. Twenty isolates each of AG- 8 and AG-2-1 collected from fields where either high or low frequencies of $\mathrm{Phz}^{+}$pseudomonads occurred 
on the roots of cereal or grain legume crops were tested for sensitivity to PCA (Table 5). The $\mathrm{ED}_{50}$ of isolates of AG-8 collected from fields with high and low frequencies of $\mathrm{Phz}^{+}$pseudomonads ranged from 5 to 13 and 6 to $12 \mu \mathrm{g} / \mathrm{ml}$, respectively, and AG-2-1 isolates from high- and low-frequency $\mathrm{Phz}^{+}$fields ranged from 8 to 16 and 5 to $12 \mu \mathrm{g} / \mathrm{ml}$, respectively. The mean $\mathrm{ED}_{50}$ values for all isolates of $\mathrm{AG}-8$ from high and low $\mathrm{Phz}^{+}$frequency fields were 10.6 and $9.2 \mu \mathrm{g} / \mathrm{ml}$, respectively. For AG-2-1, the values were 10.8 and $9.1 \mu \mathrm{g} / \mathrm{ml}$. Mean $\mathrm{ED}_{50}$ values for

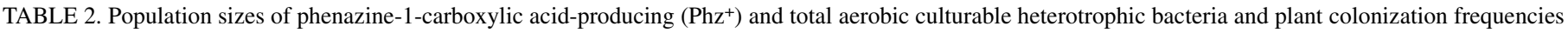
on crops from fields in the Inland Pacific Northwest collected in 2010

\begin{tabular}{|c|c|c|c|c|c|c|c|c|}
\hline Date $^{r}$ & Location $^{\text {s }}$ & Crop $^{t}$ & GPS coordinates ${ }^{\mathrm{u}}$ & Precip $(\mathrm{mm})^{\mathrm{v}}$ & Total $(\mathrm{CFU} \pm \mathrm{SD})^{\mathrm{w}}$ & $\mathrm{Phz}^{+}(\mathrm{CFU} \pm \mathrm{SD})^{\mathrm{w}}$ & Freq $(\%)^{x}$ & Cult $(\%)^{\mathrm{y}}$ \\
\hline 14 May & Dusty $^{z}$ & WW & $\mathrm{N}: 46^{\circ} 51.902^{\prime}, \mathrm{W}: 117^{\circ} 42.162^{\prime}$ & 470 & $8.0 \pm 0.4$ & ND & $0 / 12(0)$ & 0 \\
\hline 14 May & La Crosse & SW & $\mathrm{N}: 46^{\circ} 48.578^{\prime}, \mathrm{W}: 117^{\circ} 53.124^{\prime}$ & 371 & $8.3 \pm 0.6$ & $6.3 \pm 0.9$ & $11 / 12(91.7)$ & 1 \\
\hline 14 May & Hooper & WW & $\mathrm{N}: 46^{\circ} 47.468^{\prime}, \mathrm{W}: 118^{\circ} 10.148^{\prime}$ & 320 & $8.1 \pm 0.3$ & $6.3 \pm 0.5$ & $12 / 12(100)$ & 1.6 \\
\hline 14 May & Hooper & SW & $\mathrm{N}: 46^{\circ} 47.468^{\prime}, \mathrm{W}: 118^{\circ} 10.148^{\prime}$ & 320 & $8.3 \pm 0.6$ & $6.7 \pm 0.5$ & $12 / 12(100)$ & 2.5 \\
\hline 14 May & Cunningham & WW & $\mathrm{N}: 46^{\circ} 49.378^{\prime}, \mathrm{W}: 118^{\circ} 40.283^{\prime}$ & 231 & $8.4 \pm 0.5$ & $6.4 \pm 0.9$ & $12 / 12(100)$ & 1 \\
\hline 14 May & $\operatorname{Lind}^{\mathrm{z}}$ & WW & $\mathrm{N}: 47^{\circ} 0.320^{\prime}, \mathrm{W}: 118^{\circ} 34.280^{\prime}$ & 252 & $7.7 \pm 0.6$ & $6.4 \pm 0.8$ & $12 / 12(100)$ & 5 \\
\hline 14 May & Lind & SW & $\mathrm{N}: 47^{\circ} 0.320^{\prime}, \mathrm{W}: 118^{\circ} 34.280^{\prime}$ & 252 & $7.7 \pm 0.3$ & $5.3 \pm 1.1$ & $12 / 12(100)$ & 0.4 \\
\hline 14 May & Ritzville $^{z}$ & WW & $\mathrm{N}: 47^{\circ} 8.198^{\prime}, \mathrm{W}: 118^{\circ} 28.377^{\prime}$ & 303 & $7.7 \pm 0.5$ & $6.3 \pm 0.5$ & $8 / 12(66.7)$ & 4 \\
\hline 14 May & Marcellus & WW & $\mathrm{N}: 47^{\circ} 12.346^{\prime}, \mathrm{W}: 118^{\circ} 23.138^{\prime}$ & 320 & $7.8 \pm 0.4$ & $5.7 \pm 0.9$ & $8 / 12(66.7)$ & 0.8 \\
\hline 14 May & Odessa & WW & $\mathrm{N}: 47^{\circ} 12.410^{\prime}, \mathrm{W}: 118^{\circ} 41.273^{\prime}$ & 358 & $7.8 \pm 0.5$ & $5.9 \pm 1.1$ & $12 / 12(100)$ & 1.3 \\
\hline 14 May & Scharg & WW & $\mathrm{N}: 47^{\circ} 07.185^{\prime}, \mathrm{W}: 118^{\circ} 54.971^{\prime}$ & 413 & $7.9 \pm 0.5$ & $5.9 \pm 0.9$ & $12 / 12(100)$ & 1 \\
\hline 14 May & Lind & WW & $\mathrm{N}: 47^{\circ} 6.041^{\prime}, \mathrm{W}: 118^{\circ} 53.035^{\prime}$ & 252 & $7.7 \pm 0.4$ & $6.1 \pm 1.3$ & $11 / 12(91.7)$ & 2.4 \\
\hline 14 May & Connell ${ }^{\mathrm{z}}$ & WW & $\mathrm{N}: 46^{\circ} 37.267^{\prime}, \mathrm{W}: 118^{\circ} 46.320^{\prime}$ & 396 & $7.4 \pm 0.7$ & $5.9 \pm 1.0$ & $11 / 12(91.7)$ & 3.2 \\
\hline 14 May & Kahlotus & WW & $\mathrm{N}: 46^{\circ} 38.635^{\prime}, \mathrm{W}: 118^{\circ} 33.487^{\prime}$ & 321 & $7.9 \pm 0.6$ & $5.1 \pm 0.8$ & $11 / 12(91.7)$ & 0.2 \\
\hline 20 May & Chambers & $\mathrm{SC}$ & $\mathrm{N}: 46^{\circ} 40.342^{\prime}, \mathrm{W}: 117^{\circ} 11.802^{\prime}$ & 574 & $8.2 \pm 0.5$ & ND & $0 / 12(0)$ & 0 \\
\hline 20 May & Wawawai & SP & $\mathrm{N}: 46^{\circ} 36.166^{\prime}, \mathrm{W}: 117^{\circ} 9.993^{\prime}$ & 484 & $8.9 \pm 0.5$ & ND & $0 / 12(0)$ & 0 \\
\hline 20 May & Uniontown & WW & $\mathrm{N}: 46^{\circ} 30.591^{\prime}, \mathrm{W}: 117^{\circ} 4.896^{\prime}$ & 603 & $8.2 \pm 0.4$ & $5.4 \pm 0.2$ & $3 / 12(25)$ & 0.2 \\
\hline 20 May & Chard & WW & $\mathrm{N}: 46^{\circ} 32.398^{\prime}, \mathrm{W}: 117^{\circ} 51.797^{\prime}$ & 411 & $8.3 \pm 0.4$ & $5.6 \pm 0.8$ & $12 / 12(100)$ & 0.2 \\
\hline 20 May & Whetstone & SW & $\mathrm{N}: 46^{\circ} 23.809^{\prime}, \mathrm{W}: 117^{\circ} 55.944^{\prime}$ & 307 & $8.1 \pm 0.4$ & $6.8 \pm 0.7$ & $8 / 12(66.7)$ & 5 \\
\hline 20 May & Ronan & SP & $\mathrm{N}: 46^{\circ} 22.036^{\prime}, \mathrm{W}: 117^{\circ} 55.726^{\prime}$ & 413 & $8.0 \pm 0.7$ & $7.1 \pm 0$ & $1 / 12(8.3)$ & 12.5 \\
\hline 20 May & Waitsburg ${ }^{\mathrm{z}}$ & WW & $\mathrm{N}: 46^{\circ} 16.347^{\prime}, \mathrm{W}: 118^{\circ} 7.675^{\prime}$ & 485 & $8.5 \pm 0.5$ & $5.1 \pm 0.5$ & $6 / 12(50)$ & 0.04 \\
\hline 20 May & Coppei & $\mathrm{SC}$ & $\mathrm{N}: 46^{\circ} 13.800^{\prime}, \mathrm{W}: 118^{\circ} 8.261^{\prime}$ & 428 & $8.2 \pm 0.4$ & ND & $0 / 12(0)$ & 0 \\
\hline 20 May & Gillian & WW & $\mathrm{N}: 46^{\circ} 7.832^{\prime}, \mathrm{W}: 118^{\circ} 11.055^{\prime}$ & 612 & $8.2 \pm 0.4$ & $5.9 \pm 0.6$ & $7 / 12(58.3)$ & 0.5 \\
\hline 20 May & Lowden & WW & $\mathrm{N}: 46^{\circ} 3.416^{\prime}, \mathrm{W}: 118^{\circ} 35.558^{\prime}$ & 273 & $8.4 \pm 0.4$ & $5.6 \pm 1.3$ & $8 / 12(66.7)$ & 0.2 \\
\hline 20 May & Hadley & WW & $\mathrm{N}: 46^{\circ} 6.009^{\prime}, \mathrm{W}: 118^{\circ} 22.363^{\prime}$ & 452 & $8.4 \pm 0.4$ & $6.6 \pm 1.1$ & $7 / 12(58.3)$ & 1.6 \\
\hline 20 May & Berryman & WW & $\mathrm{N}: 46^{\circ} 11.730^{\prime}, \mathrm{W}: 118^{\circ} 22.902^{\prime}$ & 343 & $8.6 \pm 0.4$ & $6.4 \pm 1.2$ & 4/12 (33.3) & 0.6 \\
\hline 20 May & Bolles & WW & $\mathrm{N}: 46^{\circ} 17.082^{\prime}, \mathrm{W}: 118^{\circ} 14.572^{\prime}$ & 436 & $8.2 \pm 0.5$ & ND & $0 / 12(0)$ & 0 \\
\hline 20 May & Colfax & SB & $\mathrm{N}: 46^{\circ} 52.432^{\prime}, \mathrm{W}: 117^{\circ} 26.043^{\prime}$ & 498 & $8.6 \pm 0.3$ & ND & $0 / 12(0)$ & 0 \\
\hline 7 June & St. John ${ }^{z}$ & SW & $\mathrm{N}: 47^{\circ} 4.845^{\prime}, \mathrm{W}: 117^{\circ} 31.218^{\prime}$ & 546 & $8.7 \pm 0.4$ & ND & $0 / 12(0)$ & 0 \\
\hline 7 June & Lamont & SW & $\mathrm{N}: 47^{\circ} 9.452^{\prime}, \mathrm{W}: 117^{\circ} 52.266^{\prime}$ & 413 & $8.5 \pm 0.4$ & ND & $0 / 12(0)$ & 0 \\
\hline 7 June & Sprague & WW & $\mathrm{N}: 47^{\circ} 20.318^{\prime}, \mathrm{W}: 118^{\circ} 0.215^{\prime}$ & 400 & $8.1 \pm 0.6$ & $4.3 \pm 0.8$ & $8 / 12(66.7)$ & 0.02 \\
\hline 7 June & Harrington & SW & $\mathrm{N}: 47^{\circ} 23.613^{\prime}, \mathrm{W}: 118^{\circ} 8.886^{\prime}$ & 358 & $8.9 \pm 0.5$ & ND & $0 / 12(0)$ & 0 \\
\hline 7 June & West of Edwall & SB & $\mathrm{N}: 47^{\circ} 30.057^{\prime}, \mathrm{W}: 117^{\circ} 57.360^{\prime}$ & 434 & $8.7 \pm 0.4$ & $4.7 \pm 1.2$ & $9 / 12(75)$ & 0.01 \\
\hline 7 June & Edwall & WW & $\mathrm{N}: 47^{\circ} 30.846^{\prime}, \mathrm{W}: 117^{\circ} 56.418^{\prime}$ & 423 & $7.9 \pm 0.5$ & $4.4 \pm 0.7$ & $4 / 12(33.3)$ & 0.03 \\
\hline 7 June & Edwall & SW & $\mathrm{N}: 47^{\circ} 30.846^{\prime}, \mathrm{W}: 117^{\circ} 56.418^{\prime}$ & 423 & $8.1 \pm 0.5$ & ND & $0 / 12(0)$ & 0 \\
\hline 7 June & Reardon & WW & $\mathrm{N}: 47^{\circ} 40.114^{\prime}, \mathrm{W}: 118^{\circ} 2.026^{\prime}$ & 320 & $8.1 \pm 0.4$ & ND & $0 / 12(0)$ & 0 \\
\hline 7 June & Creston & WW & $\mathrm{N}: 47^{\circ} 49.867^{\prime}, \mathrm{W}: 118^{\circ} 32.022^{\prime}$ & 323 & $8.1 \pm 0.4$ & $4.0 \pm 0.6$ & $4 / 12(33.3)$ & 0.01 \\
\hline 7 June & Almira $^{z}$ & SW & $\mathrm{N}: 47^{\circ} 48.975^{\prime}, \mathrm{W}: 118^{\circ} 51.725^{\prime}$ & 354 & $8.0 \pm 0.5$ & ND & $0 / 12(0)$ & 0 \\
\hline 7 June & Brewster & SW & $\mathrm{N}: 48^{\circ} 8.290^{\prime}, \mathrm{W}: 119^{\circ} 44.461^{\prime}$ & 326 & $8.4 \pm 0.3$ & $4.8 \pm 1.9$ & $9 / 12(75)$ & 0.03 \\
\hline 7 June & Dyer & SW & $\mathrm{N}: 48^{\circ} 0.463^{\prime}, \mathrm{W}: 119^{\circ} 45.366^{\prime}$ & 336 & $8.7 \pm 0.3$ & $7.4 \pm 0.4$ & $4 / 12(33.3)$ & 5 \\
\hline 7 June & Waterville & WW & $\mathrm{N}: 47^{\circ} 39.390^{\prime}, \mathrm{W}: 120^{\circ} 4.326^{\prime}$ & 314 & ND & $6.9 \pm 0.6$ & $5 / 12(41.7)$ & 0 \\
\hline 7 June & Moses Lake ${ }^{z}$ & WW & $\mathrm{N}: 47^{\circ} 3.449^{\prime}, \mathrm{W}: 119^{\circ} 12.864^{\prime}$ & 244 & $8.3 \pm 0.5$ & $6.5 \pm 0.7$ & $2 / 12(16.7)$ & 1.5 \\
\hline 11 June & Othello & WW & $\mathrm{N}: 46^{\circ} 47.685^{\prime}, \mathrm{W}: 118^{\circ} 58.406^{\prime}$ & 227 & $8.2 \pm 0.6$ & $6.1 \pm 1.1$ & $12 / 12(100)$ & 0.8 \\
\hline 11 June & Pullman & $\mathrm{SC}$ & $\mathrm{N}: 46^{\circ} 48.467^{\prime}, \mathrm{W}: 117^{\circ} 49.654^{\prime}$ & 560 & $8.5 \pm 0.6$ & ND & $0 / 12(0)$ & 0 \\
\hline 11 June & Palouse & SL & $\mathrm{N}: 46^{\circ} 52.878^{\prime}, \mathrm{W}: 117^{\circ} 7.511^{\prime}$ & 535 & $8.1 \pm 0.7$ & $4.8 \pm 0$ & $1 / 12(8.3)$ & 0.05 \\
\hline 11 June & Palouse & SB & $\mathrm{N}: 46^{\circ} 53.694^{\prime}, \mathrm{W}: 117^{\circ} 6.355^{\prime}$ & 535 & $8.2 \pm 0.4$ & ND & $0 / 12(0)$ & 0 \\
\hline 11 June & Grinnell & WW & $\mathrm{N}: 46^{\circ} 57.819^{\prime}, \mathrm{W}: 117^{\circ} 5.480^{\prime}$ & 474 & $8.3 \pm 0.5$ & $3.2 \pm 0$ & $1 / 12(8.3)$ & 0.0008 \\
\hline 11 June & Garfield & SW & $\mathrm{N}: 47^{\circ} 0.037^{\prime}, \mathrm{W}: 117^{\circ} 7.868^{\prime}$ & 610 & $8.4 \pm 0.4$ & ND & $0 / 12(0)$ & 0 \\
\hline 11 June & Garfield & SL & $\mathrm{N}: 47^{\circ} 2.823^{\prime}, \mathrm{W}: 117^{\circ} 9.545^{\prime}$ & 610 & $7.8 \pm 0.5$ & ND & $0 / 12(0)$ & 0 \\
\hline 11 June & Belmont & SP & $\mathrm{N}: 47^{\circ} 6.321^{\prime}, \mathrm{W}: 117^{\circ} 11.030^{\prime}$ & 567 & $7.7 \pm 0.4$ & ND & $0 / 12(0)$ & 0 \\
\hline 11 June & Tekoa & SB & $\mathrm{N}: 47^{\circ} 11.629^{\prime}, \mathrm{W}: 117^{\circ} 8.700^{\prime}$ & 516 & $8.0 \pm 0.3$ & ND & $0 / 12(0)$ & 0 \\
\hline 11 June & Latah & SL & $\mathrm{N}: 47^{\circ} 18.089^{\prime}, \mathrm{W}: 117^{\circ} 9.829^{\prime}$ & 476 & $8.0 \pm 0.4$ & $6.6 \pm 0.6$ & $2 / 12(16.7)$ & 3.9 \\
\hline 11 June & North Pine & SB & $\mathrm{N}: 47^{\circ} 16.697^{\prime}, \mathrm{W}: 117^{\circ} 21.695^{\prime}$ & 404 & $8.8 \pm 0.3$ & $6.9 \pm 0$ & $1 / 12(8.3)$ & 1.25 \\
\hline 11 June & Thornton & SW & $\mathrm{N}: 47^{\circ} 8.250^{\prime}, \mathrm{W}: 117^{\circ} 23.449^{\prime}$ & 466 & $8.0 \pm 0.8$ & ND & $0 / 12(0)$ & 0 \\
\hline 11 June & Steptoe & SP & $\mathrm{N}: 47^{\circ} 3.480^{\prime}, \mathrm{W}: 117^{\circ} 22.909^{\prime}$ & 514 & $8.6 \pm 0.4$ & ND & $0 / 12(0)$ & 0 \\
\hline 11 June & Steptoe ${ }^{z}$ & SW & $\mathrm{N}: 46^{\circ} 58.051^{\prime}, \mathrm{W}: 117^{\circ} 17.972^{\prime}$ & 514 & $8.5 \pm 0.3$ & ND & $0 / 12(0)$ & 0 \\
\hline 11 June & Steptoe & SP & $\mathrm{N}: 46^{\circ} 58.051^{\prime}, \mathrm{W}: 117^{\circ} 17.972^{\prime}$ & 514 & $8.5 \pm 0.5$ & ND & $0 / 12(0)$ & 0 \\
\hline 11 June & Colfax & SW & $\mathrm{N}: 46^{\circ} 53.872^{\prime}, \mathrm{W}: 117^{\circ} 11.304^{\prime}$ & 498 & $8.2 \pm 0.4$ & $5.2 \pm 1.2$ & $1 / 12(8.3)$ & 0.1 \\
\hline
\end{tabular}

${ }^{r}$ Date of sampling.

$s$ Isolates are from commercial fields and experimental plots near these Washington cities.

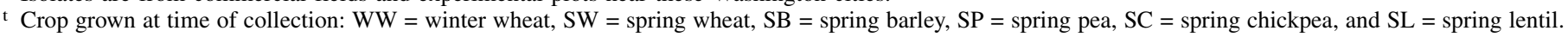

u Global positioning system (GPS) coordinates at each location were recorded using a Garmin device.

$\checkmark$ Average annual precipitation at the location (average over 30-year period).

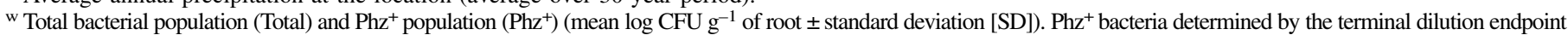
assay with $\mathrm{Phz}^{+}$primers; total culturable aerobic heterotrophic bacterial population was determined in one-tenth-strength tryptic soy broth supplemented with cycloheximide.

${ }^{x}$ Frequency of 12 individual rhizospheres colonized by $\mathrm{Phz}^{+}$bacteria.

y $\mathrm{Phz}^{+}$population as a percentage of the total culturable aerobic heterotrophic bacterial population.

$\mathrm{z}$ Washington State University variety trial. 


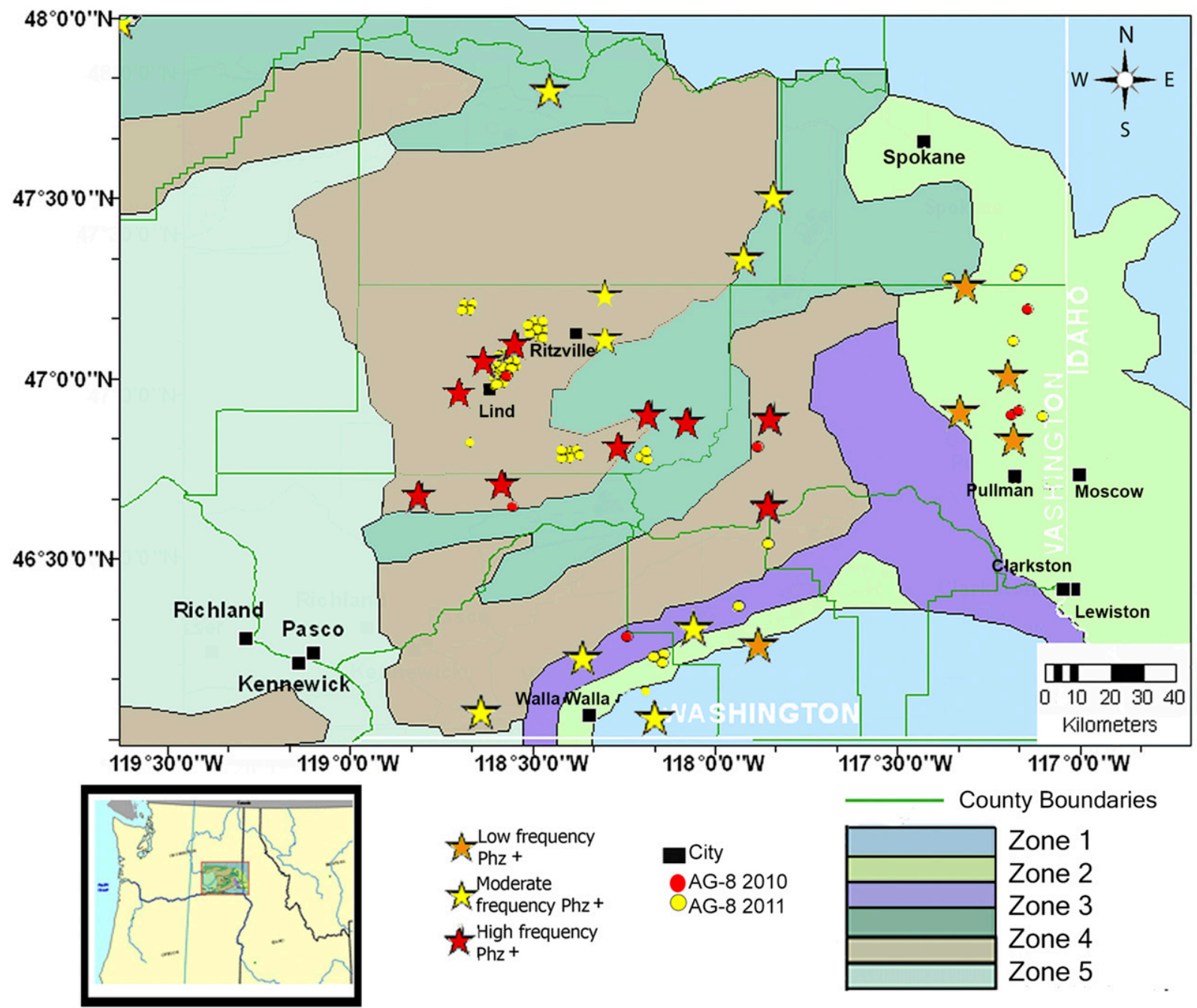

Fig. 1. Distribution of Rhizoctonia solani AG-8 isolates collected in 2010 and 2011. Original map is from Jaaffar et al. (2016), and frequency of phenazine-1carboxylic acid-producing $\left(\mathrm{Phz}^{+}\right)$pseudomonad data were overlaid on the map. Low frequency of $\mathrm{Phz}^{+}=0$ to $32 \%$ of rhizospheres colonized, moderate frequency $=33$ to $66 \%$ of rhizospheres colonized, and high frequency $=67$ to $100 \%$ of rhizospheres colonized.

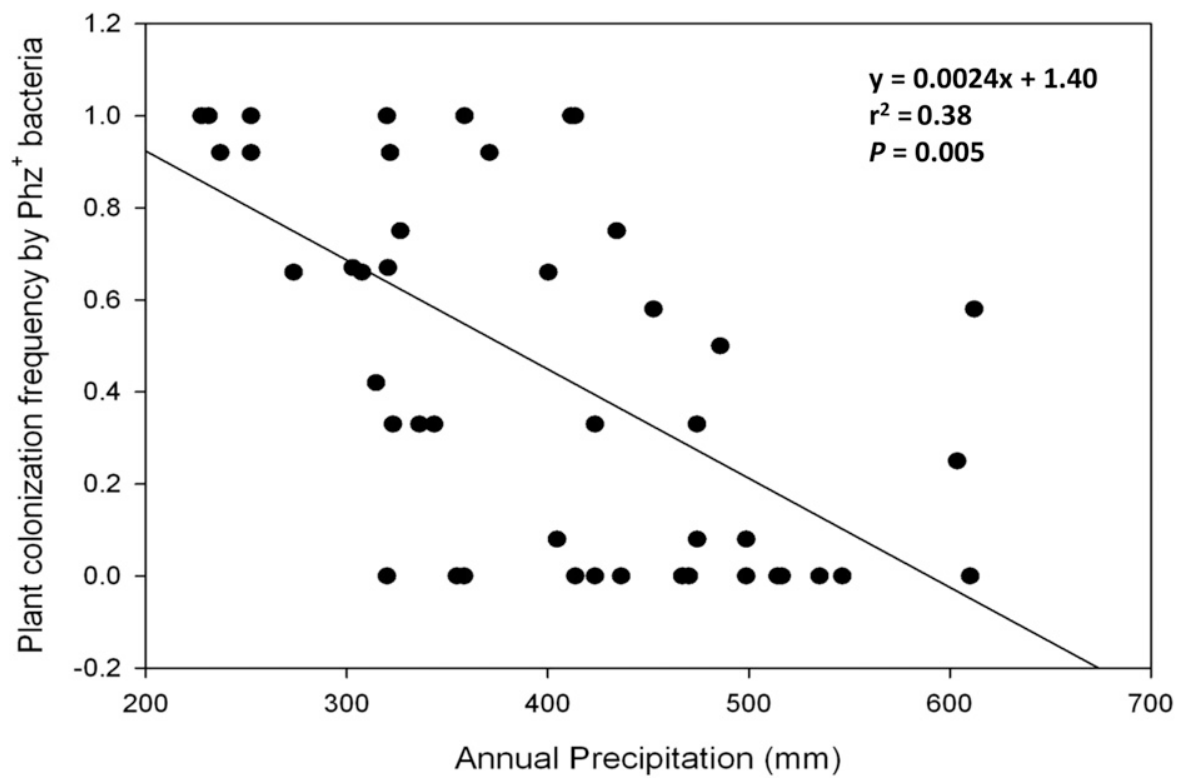

Fig. 2. Relationship between annual precipitation and frequency of plant colonization by indigenous phenazine-1-carboxylic acid-producing $\left(\mathrm{Phz} \mathrm{z}^{+}\right.$) pseudomonads in the Inland Pacific Northwest. For each location sampled (black dot), the mean colonization frequency was determined by screening 12 individual wheat rhizospheres for the presence of $\mathrm{Phz}^{+}$pseudomonads. Mean annual precipitation values were based on records for the years 1971 to 2000. 
each AG did not differ significantly between isolates from fields with low and high frequencies, and the hypothesis that these isolates developed tolerance to natural antibiotics in the field was rejected.

Pathogenicity and virulence of $R$. solani AG-8 and AG-21. The tube assay was used to test 20 field isolates each of $R$. solani AG-8 and AG-2-1 for their ability to cause root disease on wheat. AG-2-1 produced only minor root damage, manifested as browning of the roots, whereas isolates of AG-8 produced serious symptoms, including spear tips, browning, and cortical collapse. All AG-8 isolates were more virulent than AG-2-1 isolates (Table 5).

Linear regression analysis of the relationship between virulence of an isolate (as determined in the tube assay) and sensitivity to PCA (Table 5) showed no significant correlation for AG-8 isolates $(P=$ $0.9)$ (Supplementary Fig. S2). The relationship between virulence and sensitivity to PCA of AG-2-1 isolates, although statistically significant $(P=0.02)$, was determined to be not biologically significant due to the low $r^{2}$ value of the analysis (Supplementary Fig. S3). Therefore, the sensitivity of an isolate to PCA had no impact on its virulence on wheat.

Biological control of $R$. solani AG-8 by $\mathbf{P h z}^{+}$fluorescent Pseudomonas spp. Seven fluorescent Pseudomonas spp., including two isolates each of $P$. aridus, $P$. cerealis, $P$. orientalis, and $P$. synxzntha, were tested for ability to suppress Rhizoctonia root rot caused by AG- 8 isolate C- 1 in both raw and pasteurized Quincy virgin soil. Root disease ratings and plant height data for two separate experiments in raw and pasteurized soil are shown in Tables 6 and 7, respectively. All isolates suppressed AG-8 isolate C-1 in both raw and pasteurized soil on the basis of disease ratings. In experiment 1 in raw soil, strain R6-28-08 gave significantly more protection than strain 4(1):2-10 but, when the experiment was repeated (experiment 2), there was no significant difference. The reduction in root disease caused by the eight bacterial strains did not result in a consistent increase in plant height when the bacterial treatments were compared with the two inoculated controls $(\mathrm{CK}+$ $\mathrm{MC}$ and $\mathrm{CK}$ ). Thus, there were no consistent differences among $\mathrm{Phz}^{+}$pseudomonads in their biocontrol activity.

On the basis of disease ratings in pasteurized soil, there was no difference in the ability of the eight $\mathrm{Phz}^{+}$pseudomonads to suppress AG-8 isolate C-1. However, isolate S3-6:7-09 consistently showed an increase in plant height as compared with the two inoculated controls.

\section{DISCUSSION}

$R$. solani AG- 8 and $R$. oryzae, causal agents of Rhizoctonia root rot and bare patch, are ubiquitous in cereal-based cropping systems of the Columbia Plateau of the Inland PNW, yet the severity of this
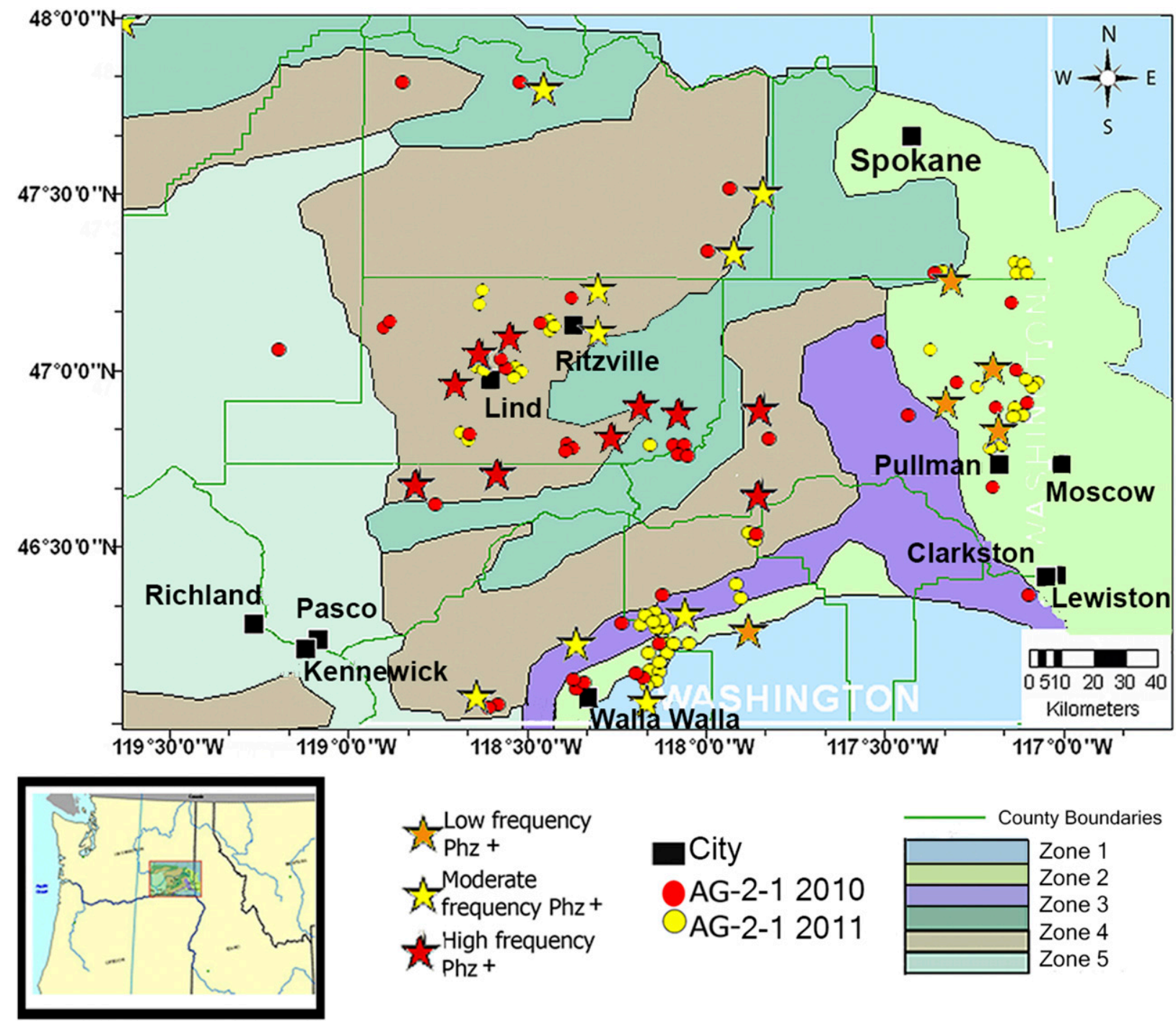

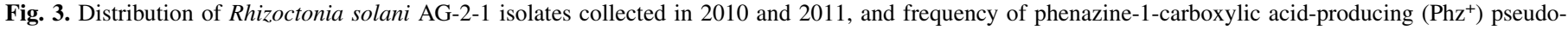

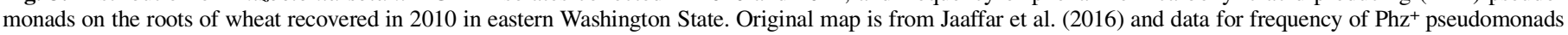

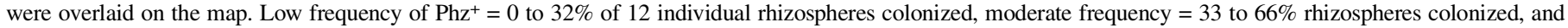
high frequency $=67$ to $100 \%$ of rhizospheres colonized. 
disease occurs differentially throughout the region (Jaaffar et al. 2016). $R$. solani AG-8 is most commonly found in the lowprecipitation zone, which encompasses agronomic zones 4, 5, and 6 (Fig. 1), and root rot and bare patch is most severe in that same region. In contrast, AG-2-1, causal agent of damping-off and root rot of canola, was more evenly distributed throughout all six agronomic zones of the Columbia Plateau (Fig. 3) (Jaaffar et al. 2016). The distribution of these and other Rhizoctonia AG and species in the Inland PNW has been described in depth by both classical and molecular approaches (Jaaffar et al. 2016; Okubara et al. 2008, 2014). $\mathrm{Phz}^{+}$fluorescent $P$ seudomonas spp. also were shown to be ubiquitous on crops throughout the Columbia Plateau of the Inland PNW (Mavrodi et al. 2012a). We show here that the geographic distribution of $\mathrm{Phz}^{+}$pseudomonads overlaps closely with the distribution of $R$. solani AG-8 but not with other Rhizoctonia AG and species.

Mavrodi et al. (2012a) hypothesized that $\mathrm{Phz}^{+}$pseudomonads play a role in the natural suppression of Rhizoctonia root rot and bare patch known to occur in fields in the Columbia Plateau of the Inland PNW (Lucas et al. 1993; Paulitz et al. 2009; Schillinger and Paulitz 2006, 2014). Rhizoctonia decline was first described in Australia (MacNish 1988; Roget et al. 1996) and disease suppressiveness develops in the soil with continual cropping of hosts susceptible to AG-8 during reduced tillage or no-till practices. Rhizoctonia decline is usually

TABLE 3. Growth rate of Rhizoctonia anastomosis groups (AG) and species in one-fifth-strength potato dextrose agar buffered to different $\mathrm{pH}$ values ${ }^{\mathrm{x}}$

\begin{tabular}{lllllll}
\hline & \multicolumn{6}{c}{ Growth rate $(\mathrm{mm} / \text { day })^{\mathrm{y}}$} \\
\cline { 2 - 7 } AG or species $^{\mathrm{n}}$ & $\mathrm{pH} \mathrm{5.4}$ & $\mathrm{pH} \mathrm{6}$ & $\mathrm{pH} 6.4$ & $\mathrm{pH} \mathrm{6.8}$ & $\mathrm{pH} \mathrm{7.2}$ & $\mathrm{pH} \mathrm{7.6}$ \\
\hline AG-8 & $6.9 \mathrm{c}$ & $6.7 \mathrm{c}$ & $6.3 \mathrm{a}$ & $3.8 \mathrm{~b}$ & $3.2 \mathrm{a}$ & $2.2 \mathrm{~b}$ \\
AG-8 & $6.7 \mathrm{~cd}$ & $6.7 \mathrm{c}$ & $5.4 \mathrm{abc}$ & $3.9 \mathrm{~b}$ & $3.3 \mathrm{a}$ & $2.0 \mathrm{~b}$ \\
AG-2-1 & $6.4 \mathrm{~d}$ & $6.0 \mathrm{~d}$ & $5.9 \mathrm{a}$ & $3.7 \mathrm{~b}$ & $1.4 \mathrm{c}$ & $0.2 \mathrm{de}$ \\
AG-2-1 & $7.5 \mathrm{~b}$ & $7.4 \mathrm{~b}$ & $4.4 \mathrm{c}$ & $2.9 \mathrm{c}$ & $1.3 \mathrm{c}$ & $0.7 \mathrm{c}$ \\
AG-I & $6.0 \mathrm{e}$ & $7.2 \mathrm{~b}$ & $5.8 \mathrm{ab}$ & $5.1 \mathrm{a}$ & $3.6 \mathrm{a}$ & $3.2 \mathrm{a}$ \\
AG-10 & $8.6 \mathrm{a}$ & $8.5 \mathrm{a}$ & $6.5 \mathrm{a}$ & $4.6 \mathrm{a}$ & $2.3 \mathrm{~b}$ & $2.0 \mathrm{~b}$ \\
Ro GII & $4.6 \mathrm{f}$ & $7.0 \mathrm{bc}$ & $4.5 \mathrm{bc}$ & $1.0 \mathrm{~d}$ & $0.7 \mathrm{~d}$ & $0.3 \mathrm{~d}$ \\
Ro GIII & $1.8 \mathrm{~g}$ & $2.7 \mathrm{e}$ & $1.0 \mathrm{~d}$ & $0 \mathrm{e}$ & $0 \mathrm{e}$ & $0 \mathrm{e}$ \\
\hline
\end{tabular}

${ }^{x}$ Growth rates of $\mathrm{AG}$ and species were compared at the indicated $\mathrm{pH}$ values.

y One-fifth strength potato dextrose agar was buffered to six different $\mathrm{pH}$ values ranging from $\mathrm{pH} 5.4$ to 7.6 with $0.2 \mathrm{M}$ phosphate buffer. Means in the same column followed by the same letter are not significantly different at $P=0.05$ according to Fisher's protected least significant difference test.

${ }^{\mathrm{z}}$ Rhizoctonia solani isolates from different AG (AG-8, AG-2-1, and AG-10), AG-I-like binucleate Rhizoctonia (AG-I), and R. oryzae groups II and III (Ro GII and Ro GIII). associated with wheat and barley production. The fact that $\mathrm{Phz}^{+}$ Pseudomonas spp. and AG-8 thrive under similar environmental and cropping conditions indicates that these two microorganisms may have overlaping niches on cereal roots, thus making $\mathrm{Phz}^{+}$bacteria ideally positioned to interact with $R$. solani AG-8. In addition, the fact that PCA occurs at greater than nanomolar quantities on roots of wheat and barley grown in the low-precipitation zone (agronomic zones 4, 5, and 6) (Mavrodi et al. 2012a), that PCA is highly inhibitory to Rhizoctonia spp. (Table 5), and that $\mathrm{Phz}^{+}$Pseudomonas spp. are highly suppressive to Rhizoctonia root rot (Tables 6 and 7) provides further support for the role of PCA producers in the natural suppression of Rhizoctonia root rot. The $\mathrm{Phz}^{+}$pseudomonads used in our biocontrol studies (Tables 6 and 7) were isolated from near Lind and Ritzville, WA, in the heart of the low-precipitation zone, where high populations of $\mathrm{Phz}^{+}$bacteria are present on nearly every wheat plant. These strains were selected for testing because they are representative of the four species indigenous to fields of the Columbia Plateau (Parejko et al. 2012). All of these strains provided similar levels of biocontrol but it is not known if they differ in rhizosphere competence and ecological fitness. A potential role for $\mathrm{Phz}^{+}$pseudomonads in natural disease suppression is not unprecedented. Phenazine-producing Pseudomonas spp. working in concert with nonpathogenic $F$. oxysporum had a major role in the natural suppression of flax wilt caused by $F$. oxysporum f. sp. lini in the Châteaurenard Fusarium wiltsuppressive soil in France (Mazurier et al. 2009).

Yin et al. (2013) examined the natural decline or suppression of Rhizoctonia patches at a location near Ritzville, WA, in the same sampling region as that studied in this article, using next-generation sequencing (454 pyrosequencing). They implicated Chyseobacterium soldanellicola in the phylum Bacteroides as one of the bacteria involved in patch decline. They identified many bacterial groups, including Sphingobacteriales and Pseudomonas spp., which were significantly higher in the rhizosphere of diseased plants in patches as compared with healthy wheat. However, the technology they used did not discriminate at finer taxonomic resolutions because it was based only on a 200- to 300-bp region of the 16S RNA. The large operational taxonomic unit identified as Pseudomonas undoubtedly contains a diversity of species, including those that produce phenazines.

Mavrodi et al. (2012a) reported that the frequency with which the rhizosphere of wheat was colonized with $\mathrm{Phz}^{+}$pseudomonads was inversely correlated with annual precipitation. They went on to hypothesize that $\mathrm{Phz}^{+}$pseudomonads are "uniquely adapted to growing and surviving in the rhizosphere under conditions of water stress and that soil moisture represents a major abiotic factor that

TABLE 4. Sensitivity to phenazine-1-carboxylic acid of isolates from different anastomosis groups (AG) of Rhizoctonia solani, binucleate Rhizoctonia AG-I, and R. oryzae

\begin{tabular}{|c|c|c|c|c|c|}
\hline Isolate $^{u}$ & Source of isolate ${ }^{v}$ & Crop $^{w}$ & Rhizoctonia spp. ${ }^{\mathrm{x}}$ & $\mathrm{ED}_{50}(\mu \mathrm{g} / \mathrm{ml})^{\mathrm{y}}$ & Mean $\mathrm{ED}_{50}(\mu \mathrm{g} / \mathrm{ml})^{\mathrm{z}}$ \\
\hline AG-8 C1 & Clyde & B & Rhizoctonia solani AG-8 & 16 & $16 \mathrm{a}$ \\
\hline T11S2-RS11 & Odessa & WW & R. solani AG-8 & 16 & \\
\hline Rh 060609-145 & Ritzville & WW & R. solani AG-I & 9 & $9.0 \mathrm{bc}$ \\
\hline Rh 080741-181 & Pullman & SW & R. solani AG-10 & 9 & $9.0 \mathrm{bc}$ \\
\hline Rh 080322-154 & Garfield & SW & R. solani AG-10 & 9 & \\
\hline T67S1-RS11 & Pullman & WW & R. solani AG-2-1 & 10 & $9.5 \mathrm{abc}$ \\
\hline T5S1-RS10 & Marcellus & WW & R. solani AG-2-1 & 9 & $\ldots$ \\
\hline T21S6-RO11 & Chard & $\mathrm{CF}$ & $R$. oryzae group II & 10 & $15 \mathrm{ab}$ \\
\hline T87S2-RO10 & Colfax & SW & $R$. oryzae group II & 20 & $\ldots$ \\
\hline T79S3-RO11 & North Pine & SB & $R$. oryzae group III & 12 & $11 \mathrm{abc}$ \\
\hline T39S3-RO10 & St. John & SW & $R$. oryzae group III & 10 & $\ldots$ \\
\hline
\end{tabular}

u Isolates were collected by using the toothpick assay as described in Jaaffar et al. (2016).

$\checkmark$ Isolates were from commercial fields and experimental plots near these Washington cities.

${ }^{\mathrm{w}}$ Crop at time of collection. $\mathrm{B}=$ barley, $\mathrm{WW}=$ winter wheat, $\mathrm{SW}=$ spring wheat, $\mathrm{F}=$ fallow, $\mathrm{CF}=$ chemical fallow, and $\mathrm{SB}=$ spring barley.

${ }^{\mathrm{x}}$ Isolates of Rhizoctonia from different AG groups and species.

${ }^{\mathrm{y}} \mathrm{ED}_{50}=50 \%$ effective dose.

${ }^{\mathrm{z}}$ Mean $\mathrm{ED}_{50}$ of two representative isolates from each group of Rhizoctonia spp. Means in the same column followed by the same letter are not significantly different at $P=0.05$ according to Fisher's protected least significant difference test. 
drives the development of the indigenous phenazine-producing microbial community." Our study both confirmed and substantially extended those results by showing a similar significant inverse correlation $\left(r^{2}=0.38, P=0.005\right)$ between annual precipitation and colonization frequency by $\mathrm{Phz}^{+}$pseudomonads (Fig. 2). The strength of this correlation is especially surprising given the great diversity of fields sampled (different management practices, fall and spring sown crops, and varieties) and that the fields were located over distances of hundreds of kilometers throughout the Columbia Plateau of the Inland PNW, which contains the largest contiguous production system in the western United States (Schillinger and Papendick 2008). The current findings fill in major gaps in our understanding of $\mathrm{Phz}^{+}$producers in the high-precipitation zone $(>450 \mathrm{~mm})$, which corresponds to agronomic zones 1 and 2 . In the study by Mavrodi et al. (2012a), there were minimal samples of $\mathrm{Phz}^{+}$pseudomonads from those zones. In the current study, the frequency of colonization of wheat and barley by $\mathrm{Phz}^{+}$pseudomonads often became undetectable at higher precipitation, which was not seen by Mavrodi et al. (2012a). Support for the conclusion of a precipitous drop in colonization frequency of $\mathrm{Phz}^{+}$pseudomonads in the high-precipitation zone is also seen in the 10 samples of pea, lentil, and chickpea: 8 of the 10 samples had no $\mathrm{Phz}^{+}$pseudomonads and the other 2 samples had colonization frequencies of 8.3 and $16.7 \%$. The frequency data from the grain legumes were omitted from the regression analysis. The finding of poor $\mathrm{Phz}^{+}$colonization in the high-precipitation zone strongly supports another report by Mavrodi et al. (2012b) that showed very low colonization frequencies of $\mathrm{Phz}^{+}$pseudomonads in irrigated fields located

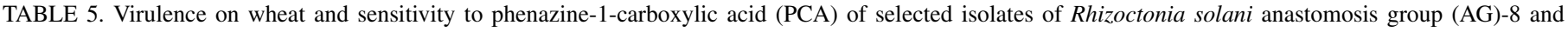
AG-2-1 from fields with low or high frequencies of PCA-producing $\left(\mathrm{Phz}^{+}\right)$isolates

\begin{tabular}{|c|c|c|c|c|c|c|c|c|c|c|}
\hline Isolate $^{\mathrm{o}}$ & Year $^{p}$ & Source $^{q}$ & Crop $^{r}$ & $\mathrm{Phz}^{+}(\mathrm{CFU} \pm \mathrm{SD})^{\mathrm{s}}$ & $\mathrm{Phz}^{+}$freq $(\%)^{\mathrm{t}}$ & $\mathrm{AG}-8^{\mathrm{u}}$ & AG-2-1 ${ }^{\mathrm{u}}$ & Rating $^{\mathrm{v}}$ & $\mathrm{ED}_{50}(\mu \mathrm{g} / \mathrm{ml})^{\mathrm{w}}$ & Mean $\mathrm{ED}_{50}(\mu \mathrm{g} / \mathrm{ml})^{\mathrm{x}}$ \\
\hline T2S2-RS10 & 2010 & La Crosse & SW & $6.3 \pm 0.9$ & $11 / 12(91.7)$ & + & $\ldots$ & 4.4 & 5 & $\ldots$ \\
\hline T8S2-RS10 & 2010 & Lind & SW & $5.3 \pm 1.1$ & $12 / 12(100)$ & + & $\ldots$ & 4.7 & 13 & $\ldots$ \\
\hline T15S2-RS10 & 2010 & Kahlotus & WW & $5.1 \pm 0.8$ & $11 / 12(91.7)$ & + & $\ldots$ & 2.9 & 12 & $\ldots$ \\
\hline T3S4-RS11 & 2011 & Hooper & SW & $6.3 \pm 0.5$ & $12 / 12(100)$ & + & $\ldots$ & 4.8 & 12 & $\ldots$ \\
\hline T6S3-RS11 & 2011 & Cunningham & WW & $6.4 \pm 0.9$ & $12 / 12(100)$ & + & $\ldots$ & 5.2 & 10 & $10.6 \mathrm{a}$ \\
\hline T7S4-RS11 & 2011 & Lind $^{y}$ & WW & $6.4 \pm 0.8$ & $12 / 12(100)$ & + & $\ldots$ & 5.4 & 12 & $\ldots$ \\
\hline T8S11-RS11 & 2011 & Lind & SW & $5.3 \pm 1.1$ & $12 / 12(100)$ & + & $\ldots$ & 5.0 & 12 & $\ldots$ \\
\hline T9S1-RS11 & 2011 & Ritzvilley $^{y}$ & WW & $6.3 \pm 0.5$ & $8 / 12(67)$ & + & $\ldots$ & 5.9 & 12 & $\ldots$ \\
\hline T11S6-RS11 & 2011 & Odessa & WW & $5.9 \pm 1.1$ & $12 / 12(100)$ & + & $\ldots$ & 4.9 & 8 & $\ldots$ \\
\hline T21S3-RS11 & 2011 & Chard & $\mathrm{CF}$ & $5.6 \pm 0.8$ & $12 / 12(100)$ & + & $\ldots$ & 4.8 & 10 & $\ldots$ \\
\hline T87S2-RS10 & 2010 & Colfax & SW & $5.2 \pm 1.2$ & $1 / 12(8.3)$ & + & $\ldots$ & 4.3 & 10 & $\ldots$ \\
\hline T76S1-RS11 & 2011 & Latah & WW & $6.6 \pm 0.6$ & $2 / 12(16.7)$ & + & $\ldots$ & 1.7 & 10 & $\ldots$ \\
\hline T25S1-RS11 & 2011 & Coppei & WW & ND & $0 / 12(0)$ & + & $\ldots$ & 5.3 & 10 & $\ldots$ \\
\hline T23S1-RS11 & 2011 & Ronan & SP & $7.1 \pm 0$ & $1 / 12(8.3)$ & + & $\ldots$ & 5.6 & 12 & $\ldots$ \\
\hline T79S2-RS11 & 2011 & North Pine & SB & $6.9 \pm 0$ & $1 / 12(8.3)$ & + & $\ldots$ & 5.0 & 6 & $9.2 \mathrm{a}$ \\
\hline T5S3-RS11 & 2011 & Marcellus & WW & ND & $0 / 12(0)$ & + & $\ldots$ & 5.6 & 10 & $\ldots$ \\
\hline T69S4-RS11 & 2011 & Palouse & SL & ND & $0 / 12(0)$ & + & $\ldots$ & 4.7 & 6 & $\ldots$ \\
\hline T73S1-RS11 & 2011 & Belmont & WW & ND & $0 / 12(0)$ & + & $\ldots$ & 4.8 & 10 & $\ldots$ \\
\hline T74S2-RS10 & 2010 & Tekoa & SB & ND & $0 / 12(0)$ & + & $\ldots$ & 2.5 & 12 & $\ldots$ \\
\hline T32S3-RS10 & 2010 & Bolles & WW & ND & $0 / 12(0)$ & + & $\ldots$ & 4.7 & 6 & $\ldots$ \\
\hline T3S2-RS10 & 2010 & Hooper & WW & $6.3 \pm 0.5$ & $12 / 12(100)$ & $\ldots$ & + & 0.8 & 16 & $\ldots$ \\
\hline T6S2-RS10 & 2010 & Cunningham & WW & $6.4 \pm 0.9$ & $12 / 12(100)$ & $\ldots$ & + & 0.6 & 10 & $\ldots$ \\
\hline T7S3-RS10 & 2010 & Lind $y$ & WW & $6.4 \pm 0.8$ & $12 / 12(100)$ & $\ldots$ & + & 0.3 & 12 & $\ldots$ \\
\hline T12S1-RS10 & 2010 & Scharg & WW & $5.9 \pm 0.9$ & $12 / 12(100)$ & $\ldots$ & + & 0.2 & 12 & $\ldots$ \\
\hline T14S2-RS10 & 2010 & Connelly & WW & $5.9 \pm 1.0$ & $11 / 12(91.7)$ & $\ldots$ & + & 0.5 & 10 & $\ldots$ \\
\hline T21S1-RS10 & 2010 & Chard & WW & $5.6 \pm 0.8$ & $12 / 12(100)$ & $\ldots$ & + & 0.3 & 8 & $10.8 \mathrm{a}$ \\
\hline T8S6-RS11 & 2011 & Lind & SW & $5.3 \pm 1.1$ & $12 / 12(100)$ & $\ldots$ & + & 0.9 & 10 & $\ldots$ \\
\hline T21S2-RS11 & 2011 & Chard & $\mathrm{CF}$ & $5.6 \pm 0.8$ & $12 / 12(100)$ & $\ldots$ & + & 0.9 & 10 & $\ldots$ \\
\hline T7S1-RS11 & 2011 & Lind $^{y}$ & WW & $6.4 \pm 0.8$ & $12 / 12(100)$ & $\ldots$ & + & 0.8 & 10 & $\ldots$ \\
\hline T9S6-RS11 & 2011 & Ritzvilley & WW & $6.3 \pm 0.5$ & $8 / 12(67)$ & $\ldots$ & + & 0.6 & 10 & $\ldots$ \\
\hline T49S3-RS10 & 2010 & Edwall & SW & ND & $0 / 12(0)$ & $\ldots$ & + & 0.6 & 10 & $\ldots$ \\
\hline T36S2-RS10 & 2010 & Colfax $(M)^{\mathrm{z}}$ & SB & ND & $0 / 12(0)$ & $\ldots$ & + & 0.6 & 10 & $\ldots$ \\
\hline T68S2-RS10 & 2010 & Palouse & SL & $4.8 \pm 0$ & $1 / 12(8.3)$ & $\ldots$ & + & 0.2 & 10 & $\ldots$ \\
\hline T79S2-RS10 & 2010 & North Pine & SB & $6.9 \pm 0$ & $1 / 12(8.3)$ & $\ldots$ & + & 0.3 & 8 & $\ldots$ \\
\hline T87S1-RS10 & 2010 & Colfax & SW & $5.2 \pm 1.2$ & $1 / 12(8.3)$ & $\ldots$ & + & 0.5 & 12 & $9.1 \mathrm{a}$ \\
\hline T23S2-RS11 & 2011 & Ronan & SP & $7.1 \pm 0$ & $1 / 12(8.3)$ & $\ldots$ & + & 0.8 & 10 & $\ldots$ \\
\hline T70S1-RS11 & 2011 & Grinnell & $\mathrm{F}$ & $3.2 \pm 0$ & $1 / 12(8.3)$ & $\ldots$ & + & 1.2 & 5 & $\ldots$ \\
\hline T70S2-RS11 & 2011 & Grinnell & $\mathrm{F}$ & $3.2 \pm 0$ & $1 / 12(8.3)$ & $\ldots$ & + & 1.0 & 10 & $\ldots$ \\
\hline T79S1-RS11 & 2011 & North Pine & SB & $6.9 \pm 0$ & $1 / 12(8.3)$ & $\ldots$ & + & 0.8 & 8 & $\ldots$ \\
\hline T87S2-RS11 & 2011 & Colfax & WW & $5.2 \pm 1.2$ & $1 / 12(8.3)$ & $\ldots$ & + & 0.6 & 8 & $\ldots$ \\
\hline
\end{tabular}

o Isolates were collected by using the toothpick assay as described in Jaaffar et al. (2016).

p Year collected.

q Isolates were from commercial fields and experimental plots near these Washington cities.

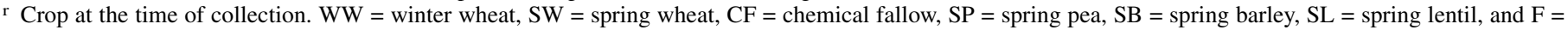
fallow.

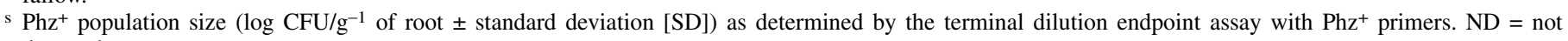
detected.

t Frequency of 12 individual rhizospheres colonized by $\mathrm{Phz}^{+}$bacteria.

u Isolates of Rhizoctonia solani AG-8 and AG-2-1 from fields with low or high frequencies of root colonization by Phz ${ }^{+}$bacteria.

$\checkmark$ Root rot disease rating on wheat, where $0=$ no disease and $8=$ dead or nearly dead at 4 weeks after planting.

${ }^{\mathrm{w}} \mathrm{ED}_{50}=50 \%$ effective dose of PCA for each isolate.

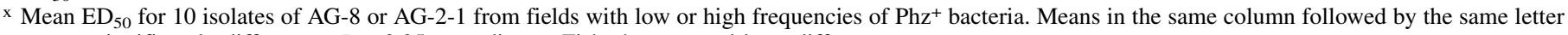
are not significantly different at $P=0.05$ according to Fisher's protected least difference.

y Washington State University variety trial site.

z Colfax, McGregor Farm. 
adjacent to dryland wheat supporting high $\mathrm{Phz}^{+}$populations in the low-precipitation zone. Irrigated wheat in the low-precipitation zone may receive as much as $23 \mathrm{~cm}$ of water between April and June, making the precipitation in an irrigated field as great as or greater than precipitation in the high-precipitation zone.

Historically, it has been thought that fluorescent pseudomonads, which are highly adapted to growing and surviving on roots and in the rhizosphere, thrive under high soil moisture conditions that are at or near field capacity (Howie et al. 1987; Mavrodi et al. 2012b; Weller 2007). In fact, the issue of inconsistent colonization by introduced pseudomonads as biocontrol agents of soilborne pathogens has been attributed, in part, to insufficient soil moisture for colonization (Weller 1988, 2007). The findings of the current study and those of Mavrodi et al. (2012a,b) completely alter accepted principles about fluorescent pseudomonads that provide biocontrol and the environmental conditions required for biocontrol. The reason why $\mathrm{Phz}^{+}$ pseudomonads thrive and produce PCA in such an arid agroecosystem as the low-precipitation zone remains unclear and is a major topic of ongoing research. Mavrodi et al. (2012b) suggested that soil moisture levels change the amount or composition of root exudates which, in turn, affects the growth and competitiveness of indigenous pseudomonads. Thus, $\mathrm{Phz}^{+}$pseudomonads would be ideally adapted to utilizing the quantity and quality of exudates produced by wheat and barley grown under water stress conditions in the low-precipitation zone. Second, they suggested that other fluorescent pseudomonads-for example, those that produce the antibiotic 2,4-diacetylphloroglucinol (DAPG) — are more competitive at higher soil moisture and displace $\mathrm{Phz}^{+}$pseudomonads in the rhizosphere. Mavrodi et al. (2012b) identified a striking decline in populations of $\mathrm{Phz}^{+}$pseudomonads in the rhizosphere of wheat growing in an irrigated field when DAPG-producing pseudomonads also colonized the roots. A third possibility (Mavrodi et al. 2012b) is that $\mathrm{Phz}^{+}$pseudomonads are much better adapted for survival under conditions of extended moisture stress than other pseudomonads because of the production of PCA. Pseudomonads, like other bacteria on root surfaces and in the rhizosphere, form structurally complex colonies enmeshed in mucilage called biofilms (Bloemberg et al. 2000; Chin-A-Woeng et al. 1998). The formation of biofilms is one of the physiological and molecular mechanisms underpinning the protection of bacteria against chemical and physical environmental stresses and adaption to survival in low-moisture habitats (Bloemberg et al. 2000; Harris 1980). Phenazines have been directly linked to the formation and architecture of biofilms (Maddula et al. 2006, 2008; Mavrodi et al. 2006), and Price-Whelan et al. (2006) hypothesized that, because the rate of diffusion of oxygen through biofilms is low, phenazines help to maintain the redox homeostasis of cells in the biofilm by serving as electron acceptors for the reoxidation of NADH.

It is well known that application of antibiotics in human therapy, animal production, and plant protection contributes to the emergence of antibiotic resistance in pathogens (Martínez 2008; McManus et al. 2002; Wang and Schaffner 2011). The majority of antibiotics currently used to treat human, animal, and plant diseases caused by bacteria have an environmental origin, and are most commonly isolated from soil organisms (Martínez 2008). Although a tremendous amount is known about antibiotic resistance genes and their transfer through pathogen populations, virtually nothing is known about the development of resistance in microorganisms in natural habitats to naturally occurring antibiotics.

TABLE 6. Biological control of Rhizoctonia solani AG- 8 isolate C-1 in natural soil by phenazine-1-carboxylic acid-producing Pseudomonas spp. ${ }^{\mathrm{x}}$

\begin{tabular}{|c|c|c|c|c|c|}
\hline \multirow[b]{2}{*}{ Treatment ${ }^{y}$} & \multirow[b]{2}{*}{ Source ${ }^{z}$} & \multicolumn{2}{|c|}{ Disease rating (0-to- 8 scale) } & \multicolumn{2}{|c|}{ Plant height $(\mathrm{mm})($ mean $\pm \mathrm{SD})$} \\
\hline & & Exp 1 & Exp 2 & Exp 1 & Exp 2 \\
\hline L1-45-08, Pseudomonas cerealis & Lind & $3.05 \mathrm{bc}$ & $2.61 \mathrm{~b}$ & $22.09 \pm 3.83 \mathrm{bcd}$ & $22.83 \pm 3.62 \mathrm{abcd}$ \\
\hline $4(1): 2-10$, P. cerealis & Lind & $2.94 \mathrm{~cd}$ & $2.70 \mathrm{~b}$ & $21.39 \pm 4.17 \mathrm{~cd}$ & $22.34 \pm 3.75 \mathrm{bcde}$ \\
\hline S3-6:7-09, P. aridus & Lind & $2.60 \mathrm{cde}$ & $2.23 \mathrm{~b}$ & $21.89 \pm 3.30 \mathrm{bcd}$ & $22.02 \pm 3.09 \mathrm{de}$ \\
\hline L1-3-08, $P$. orientalis & Lind & 2.72 cde & $2.47 \mathrm{~b}$ & $22.36 \pm 2.74 b c$ & $23.19 \pm 3.49 \mathrm{ab}$ \\
\hline $\mathrm{R} 2-66-08 \mathrm{~W}$, P. orientalis & Ritzville & $2.81 \mathrm{cde}$ & $2.51 \mathrm{~b}$ & $21.32 \pm 4.15 \mathrm{~cd}$ & $22.63 \pm 3.08 \mathrm{abcd}$ \\
\hline $\mathrm{CK}+\mathrm{MC}$ & $\ldots$ & $3.57 \mathrm{ab}$ & $3.42 \mathrm{a}$ & $20.96 \pm 3.04 \mathrm{~d}$ & $21.24 \pm 3.23 \mathrm{e}$ \\
\hline $\mathrm{CK}$ & $\ldots$ & $3.89 \mathrm{a}$ & $3.50 \mathrm{a}$ & $21.68 \pm 3.70 \mathrm{bcd}$ & $22.49 \pm 3.33 \mathrm{abcd}$ \\
\hline
\end{tabular}

${ }^{\mathrm{x}}$ Experiments (Exp) were conducted in Quincy virgin soil. Means in the same column followed by the same letter are not significantly different at $P=0.05$ according to Fisher's protected least significant difference (for plant height) or Kruskal-Wallis all-pairwise comparison (for disease rating). Disease ratings and plant height measurements were taken at 4 weeks. $\mathrm{SD}=$ standard deviation.

y Bacteria were applied to the seed with methyl cellulose $(\mathrm{MC})$ at a dose of $10^{7}$ seed $^{-1}$; CK $+\mathrm{MC}=$ seed treated with $1 \% \mathrm{MC}$ only and CK $=$ no seed treatment.

$\mathrm{z}$ Isolates are from commercial fields in the low-precipitation zone of the Columbia Plateau of the Inland Pacific Northwest.

TABLE 7. Biological control of Rhizoctonia solani AG-8 isolate C-1 in pasteurized soil by phenazine-1-carboxylic acid-producing Pseudomonas spp. ${ }^{\mathrm{x}}$

\begin{tabular}{|c|c|c|c|c|c|}
\hline \multirow[b]{2}{*}{ Treatment ${ }^{y}$} & \multirow[b]{2}{*}{ Source ${ }^{\mathrm{z}}$} & \multicolumn{2}{|c|}{ Disease rating ( 0 -to- 8 scale) } & \multicolumn{2}{|c|}{ Plant height $(\mathrm{mm})($ mean $\pm \mathrm{SD})$} \\
\hline & & Experiment 1 & Experiment 2 & Experiment 1 & Experiment 2 \\
\hline L1-45-08, Pseudomonas cerealis & Lind & $2.44 \pm 0.76 \mathrm{bc}$ & $2.30 \pm 0.67 \mathrm{~b}$ & $21.58 \pm 2.81 \mathrm{bcd}$ & $25.13 \pm 3.50 \mathrm{abc}$ \\
\hline S3-6:7-09, $P$. aridus & Lind & $2.46 \pm 0.69 \mathrm{bc}$ & $2.37 \pm 0.54 \mathrm{~b}$ & $21.99 \pm 3.00 \mathrm{~b}$ & $25.97 \pm 2.10 \mathrm{a}$ \\
\hline L1-3-08, $P$. orientalis & Lind & $2.45 \pm 0.56 b c$ & $2.32 \pm 0.53 b$ & $21.72 \pm 2.38 \mathrm{bcd}$ & $25.27 \pm 2.88 \mathrm{ab}$ \\
\hline $\mathrm{R} 2-66-08 \mathrm{~W}, P$. orientalis & Ritzville & $2.26 \pm 0.72 b c$ & $2.47 \pm 0.87 \mathrm{~b}$ & $21.78 \pm 2.62 \mathrm{bcd}$ & $24.00 \pm 3.65 \mathrm{cde}$ \\
\hline $\mathrm{CK}+\mathrm{MC}$ & $\ldots$ & $3.50 \pm 0.67 \mathrm{a}$ & $3.50 \pm 0.89 a$ & $20.92 \pm 3.11 \mathrm{~d}$ & $23.71 \pm 3.92 \mathrm{de}$ \\
\hline CK & $\ldots$ & $3.68 \pm 0.64 \mathrm{a}$ & $3.70 \pm 0.80 \mathrm{a}$ & $21.13 \pm 2.29 \mathrm{~cd}$ & $23.16 \pm 4.59 \mathrm{e}$ \\
\hline
\end{tabular}

${ }^{\mathrm{x}}$ Experiments were conducted in pasteurized Quincy virgin soil $\left(60^{\circ} \mathrm{C}, 30 \mathrm{~min}\right)$. Means in the same column followed by the same letter are not significantly different at $P=0.05$ according to Fisher's protected least significant difference (for plant height) or Kruskal-Wallis all-pairwise comparison (for disease rating). Disease ratings and plant height measurements were taken at 4 weeks. SD $=$ standard deviation.

${ }^{y}$ Bacteria were applied to the seed with methylcellulose $(\mathrm{MC})$ at a dose of $10^{7}$ seed $^{-1}$. CK $+\mathrm{MC}=$ seed treated with $\mathrm{MC}$ only and $\mathrm{CK}=$ no seed treatment.

${ }^{\mathrm{z}}$ Isolates are from commercial fields in the low-precipitation zone of the Columbia Plateau of the Inland Pacific Northwest. 
An important question of this study was: Can a pathogen develop resistance to an antibiotic produced by a biocontrol agent in a natural habitat such as the rhizosphere? The finding of high populations of $\mathrm{Phz}^{+}$fluorescent pseudomonads and accumulation of greater than nanomolar quantities of PCA on the roots of dryland wheat in the lowprecipitation zone (Mavrodi et al. 2012a) and the finding that $R$. solani AG-8 and AG-2-1 are ubiquitous in fields in the Columbia Plateau of the Inland PNW (Jaaffar et al. 2016; Okubara et al. 2014) indicated that this agroecosystem provided an ideal field laboratory for testing this question. Therefore, isolates of AG-8 and AG-2-1 were selected from fields in the low- and high-precipitation zones where $\mathrm{Phz}^{+}$ pseudomonads occurred at either high or low frequency on the roots of wheat. Because the amount of PCA on a cereal root system was directly related to the population size of $\mathrm{Phz}^{+}$pseudomonads colonizing the roots (Mavrodi et al. 2012a), it was assumed that Rhizoctonia isolates from fields with a high frequency of $\mathrm{Phz}^{+}$ pseudomonads would, over decades, be exposed more frequently to inhibitory concentrations of PCA than isolates from fields with a low frequency of $\mathrm{Phz}^{+}$pseudomonads. In the low-precipitation zone, wheat has been grown for over 125 years (Mavrodi et al. 2012a).

In the in vitro assay used to test the sensitivity of Rhizoctonia isolates to PCA, the medium was buffered to $\mathrm{pH} 6$ because it was shown to be optimal for growth of all of the AG and species tested, and it is also a $\mathrm{pH}$ at which PCA is active (Ownley et al. 1992). The activity of PCA previously was shown to be related to the concentration of protonated PCA, and inhibition of G. graminis var. tritici by PCA and strain 2-79 in vitro declined as alkalinity increased (Brisbane et al. 1987). Isolates of $R$. solani AG-8 and AG-2-1 from the high- and low-precipitation zones showed no significant difference in sensitivity to PCA as determined by $\mathrm{ED}_{50}$ values (Table 6), indicating that long-term exposure of Rhizoctonia spp. to PCA did not result in the development of resistance or tolerance in the pathogen to the antibiotic. The current findings are similar to those of Kwak et al. (2009), who showed that long-term exposure of G. graminis var. tritici to DAPG in take-all decline fields with high populations of DAPG-producing pseudomonads did not result in the take-all pathogen becoming less sensitive to the antibiotic. Using a Saccharomyces cerevisiae genome-wide mutant screen, Kwak et al. (2011) went on to show that resistance to DAPG probably does not develop because the antibiotic affects multiple basic cellular processes, including membrane function, reactive oxygen regulation, and cell homeostasis. Similar studies have not been conducted with PCA to determine its mechanisms of action but it is likely that this antibiotic also attacks multiple cellular processes, making it unlikely for resistance to develop. A study with pyocyanin, a derivative of PCA produced by $P$. aeruginosa, showed that this phenazine acts on major cellular pathways involved in the cell cycle, electron transport and respiration, protein sorting, vesicle transport, and the vacuolar ATPase (Ran et al. 2003).

In conclusion, an overarching question that should continue to drive research on $\mathrm{Phz}^{+}$pseudomonads in the Columbia Plateau of the Inland PNW is: What role do $\mathrm{Phz}^{+}$pseudomonads play in the natural suppression of Rhizoctonia root rot and in the sustainability of wheat production in the Columbia Plateau?

\section{ACKNOWLEDGMENTS}

We thank J. Krauser for her assistance in the preparation of the figures and tables. This work was supported by the United States Department of Agriculture (USDA) National Institute of Food and Agriculture award 2011-67019-30212. Mention of trade names or commercial products in this publication is solely for the purpose of providing specific information and does not imply recommendation or endorsement by the U.S. Department of Agriculture. USDA is an equal opportunity provider and employer.

\section{LITERATURE CITED}

Bloemberg, G. V., Wijfjes, A. H., Lamers, G. E., Stuurman, N., and Lugtenberg, B. J. 2000. Simultaneous imaging of Pseudomonas fluorescens WCS365 populations expressing three different autofluorescent proteins in the rhizosphere: New perspectives for studying microbial communities. Mol. Plant-Microbe Interact. 13:1170-1176.

Brisbane, P. G., Janik, L. J., Tate, M. E., and Warren, R. F. O. 1987. Revised structure for the phenazine antibiotic from Pseudomonas fluorescens 2-79 (NRRL B-15132). Antimicrob. Agents Chemother. 31:1967-1971.

Chin-A-Woeng, T. F. C., Bloemberg, G. V., and Lugtenberg, B. J. J. 2003. Phenazines and their role in biocontrol by Pseudomonas bacteria. New Phytol. 157:503-523.

Chin-A-Woeng, T. F. C., Bloemberg, G. V., van der Bij, A. J., van der Drift, K. M. G. M., Schripsema, J., Kroon, B., Scheffer, R. J., Keel, C., Bakker, P. A. H. M., Tichy, H. V., de Bruijn, F. J., Thomas-Oates, J. E., and Lugtenberg, B. J. J. 1998. Biocontrol by phenazine-1-carboxamideproducing Pseudomonas chlororaphis PCL1391 of tomato root rot caused by Fusarium oxysporum f. sp. radicis-lycopersici. Mol. PlantMicrobe Interact. 11:1069-1077.

D’aes, J., Hoang Hua, G. K., De Maeyer, K., Pannecoucque, J., Forrez, I., Ongena, M., Dietrich, L. E. P., Thomashow, L. S., Mavrodi, D. V., and Höfte, M. 2011. Biological control of Rhizoctonia root rot on bean by phenazine and cyclic lipopeptide- producing Pseudomonas CMR12a. Phytopathology 101:996-1004.

Harris, R. F. 1980. Effect of water potential on microbial growth and activity. Pages 23-95 in: Water Potential Relations in Soil Microbiology. J. F. Parr, W. R. Gardner, and L. F. Elliott, eds. Soil Science Society of America, Madison, WI.

Higginbotham, R. W., Paulitz, T. C., and Kidwell, K. K. 2004. Virulence of Pythium species isolated from wheat fields in eastern Washington. Plant Dis. 88:1021-1026.

Howie, W. J., Cook, R. J., and Weller, D. M. 1987. Effects of soil matric potential and cell motility on wheat root colonization by fluorescent pseudomonads suppressive to take-all. Phytopathology 77:286-292.

Huang, Z., Bonsall, R. F., Mavrodi, D. V., Weller, D. M., and Thomashow, L. S. 2004. Transformation of Pseudomonas fluorescens with genes for biosynthesis of phenazine-1-carboxylic acid improves biocontrol of Rhizoctonia root rot and in situ antibiotic production. FEMS Microbiol. Ecol. 49:243-251.

Jaaffar, A. K. M., Paulitz, T. C., Schroeder, K. L., Thomashow, L. S., and Weller, D. M. 2016. Molecular characterization, morphological characteristics, virulence, and geographic distribution of Rhizoctonia species in Washington State. Phytopathology 106:459-473.

King, E. O., Ward, M. K., and Raney, D. E. 1954. Two simple media for the demonstration of pyocyanin and fluorescein. J. Lab. Clin. Med. 44:301-307.

Kwak, Y.-S., Bakker, P. A. H. M., Glandorf, D. C. M., Rice, J. T., Paulitz, T. C., and Weller, D. M. 2009. Diversity, virulence, and 2,4-diacetylphloroglucinol sensitivity of Gaeumannomyces graminis var. tritici isolates from Washington State. Phytopathology 99:472-479.

Kwak, Y.-S., Han, S., Thomashow, L. S., Rice, J. T., Paulitz, T. C., Kim, D., and Weller, D. M. 2011. Saccharomyces cerevisiae genome-wide mutant screen for sensitivity to 2,4-diacetylphloroglucinol, an antibiotic produced by Pseudomonas fluorescens. Appl. Environ. Microbiol. 77:1770-1776.

Lucas, P., Smiley, R. W., and Collins, H. P. 1993. Decline of Rhizoctonia root rot on wheat in soils infested with Rhizoctonia solani AG-8. Phytopathology 83:260-265.

MacNish, G. C. 1988. Changes in take-all (Gaeumannomyces graminis var. tritici) Rhizoctonia root rot (Rhizoctonia solani) and soil $\mathrm{pH}$ in continuous wheat with annual applications of nitrogenous fertilizer in Western Australia. Aust. J. Exp. Agric. 28:333-341.

Maddula, V. S., Pierson, E. A., and Pierson, L. S., III. 2008. Altering the ratio of phenazines in Pseudomonas chlororaphis (aureofaciens) strain 30-84: Effects on biofilm formation and pathogen inhibition. J. Bacteriol. 190:2759-2766.

Maddula, V. S., Zhang, Z., Pierson, E. A., and Pierson, L. S., III. 2006. Quorum sensing and phenazines are involved in biofilm formation by Pseudomonas chlororaphis (aureofaciens) strain 30-84. Microb. Ecol. 52:289-301.

Martínez, J. 2008. Antibiotics and antibiotic resistance genes in natural environments. Science 321:365-367.

Mavrodi, D., Blankenfeldt, W., and Thomashow, L. S. 2006. Phenazine compounds in fluorescent Pseudomonas spp.: Biosynthesis and regulation. Annu. Rev. Phytopathol. 44:417-445.

Mavrodi, D. V., Mavrodi, O. V., Parejko, J. A., Bonsall, R. F., Kwak, Y.-S., Paulitz, T. C., Thomashow, L. S., and Weller, D. M. 2012a. Accumulation of the antibiotic phenazine-1-carboxylic acid in the rhizosphere of dryland cereals. Appl. Environ. Microbiol. 78:804-812.

Mavrodi, D. V., Peever, T. L., Mavrodi, O. V., Parejko, J. A., Raaijmakers, J. M., Lemanceau, P., Mazurier, S., Heide, L., Blankenfeldt, W., Weller, D. M., and Thomashow, L. S. 2010. Diversity and evolution of the phenazine biosynthesis pathway. Appl. Environ. Microbiol. 76:866-879.

Mavrodi, O. V., Mavrodi, D. V., Parejko, J. A., Thomashow, L. S., and Weller, D. M. 2012b. Irrigation differentially impacts populations of indigenous antibiotic-producing Pseudomonas spp. in the rhizosphere of wheat. Appl. Environ. Microbiol. 78:3214-3220. 
Mazurier, S., Corberand, T., Lemanceau, P., and Raaijmakers, J. M. 2009. Phenazine antibiotics produced by fluorescent pseudomonads contribute to natural soil suppressiveness to Fusarium wilt. ISME J. 3:977-991.

McManus, P. S., Stockwell, V. O., Sundin, G. W., and Jones, A. L. 2002. Antibiotic use in plant agriculture. Annu. Rev. Phytopathol. 40:443-465.

McSpadden Gardener, B. B., Mavrodi, D. V., Thomashow, L. S., and Weller, D. M. 2001. A rapid polymerase chain reaction-based assay characterizing rhizosphere populations of 2,4-diacetylphloroglucinol-producing bacteria. Phytopathology 91:44-54.

Okubara, P. A., Schroeder, K. L., Abatzoglou, J. T., and Paulitz, T. C. 2014. Agroecological factors correlated to soil DNA concentrations of Rhizoctonia in dryland wheat production zones of Washington State, USA. Phytopathology 104:683-691.

Okubara, P. A., Schroeder, K. L., and Paulitz, T. C. 2008. Identification and quantification of Rhizoctonia solani and R. oryzae using real-time polymerase chain reaction. Phytopathology 98:837-847.

Ownley, B. H., Weller, D. M., and Thomashow, L. S. 1992. Influence of in situ and in vitro $\mathrm{pH}$ on suppression of Gaeumannomyces graminis var. tritici by Pseudomonas fluorescens 2-79. Phytopathology 82:178-184.

Parejko, J. A., Mavrodi, D. V., Mavrodi, O. V., Weller, D. M., and Thomashow, L. S. 2012. Population structure and diversity of phenazine-1-carboxylic acid producing fluorescent Pseudomonas spp. from dryland cereal fields of central Washington State U.S. Microb. Ecol. 64:226-241.

Parejko, J. A., Mavrodi, D. V., Mavrodi, O. V., Weller, D. M., and Thomashow, L. S. 2013. Taxonomy and distribution of phenazine-producing Pseudomonas spp. in dryland agroecosystem of the Inland Pacific Northwest (U.S.). Appl. Environ. Microbiol. 79:3887-3891.

Paulitz, T. C., and Adams, K. 2003. Composition and distribution of Pythium communities in wheat fields in eastern Washington State. Phytopathology 93:867-873

Paulitz, T. C., Okubara, P. A., and Schillinger, W. F. 2006. First report of damping-off of canola caused by Rhizoctonia solani AG 2-1 in Washington State. Plant Dis. 90:829.

Paulitz, T. C., and Schroeder, K. L. 2005. A new method for the quantification of Rhizoctonia solani and R. oryzae from soil. Plant Dis. 89:767-772.

Paulitz, T. C., Schroeder, K. L., and Okubara, P. A. 2009. Integrated control of soilborne pathogens of wheat. Pages 229-245 in: Recent Developments in Management of Plant Diseases. Plant Pathology in the 21st Century, Vol. 1. U. Gisi, I. Chet, and M. Gullino, eds. Springer, Dordrecht, Heidelberg, London, and New York.

Paulitz, T. C., Smiley, R. W., and Cook, R. J. 2002. Insights into the prevalence and management of soilborne cereal pathogens under direct seeding in the Pacific Northwest, USA. Can. J. Plant Pathol. 24:416-428.

Pierson, L. S., III, and Pierson, E. A. 2010. Metabolism and function of phenazines in bacteria: Impacts on the behavior of bacteria in the environment and biotechnological processes. Appl. Microbiol. Biotechnol. 86: $1659-1670$.

Pierson, L. S., III, and Thomashow, L. S. 1992. Cloning and heterologous expression of the phenazine biosynthetic locus from Pseudomonas aureofaciens 30-84. Mol. Plant-Microbe Interact. 5:330-339.
Price-Whelan, A., Dietrich, L. E., and Newman, D. K. 2006. Rethinking 'secondary' metabolism: Physiological roles for phenazine antibiotics. Nat. Chem. Biol. 2:71-78.

Ran, H., Hassett, D. J., and Lau, G. W. 2003. Human targets of Pseudomonas aeruginosa pyocyanin. Proc. Natl. Acad. Sci. USA 100:14315-14320.

Roget, D. K., Neate, S. M., and Rovira, A. D. 1996. Effect of sowing point design and tillage practice on the incidence of Rhizoctonia root rot, take-all and cereal cyst nematode in wheat and barley. Aust. J. Exp. Agric. 36:683-693.

Schillinger, W. F., and Papendick, R. I. 2008. Then and now: 125 years of dryland wheat farming in the Inland Pacific Northwest. Agron. J. 100:S166-S182.

Schillinger, W. F., and Paulitz, T. C. 2006. Reduction of Rhizoctonia bare patch in wheat with barley rotations. Plant Dis. 90:302-306.

Schillinger, W. F., and Paulitz, T. C. 2014. Natural suppression of Rhizoctonia bare patch in a long-term no-till cropping systems experiment. Plant Dis. 98:389-394.

Schillinger, W. F., Schofstoll, S. E., and Alldredge, J. R. 2008. Available water and wheat grain yield relations in a Mediterranean climate. Field Crops Res. 109:45-49.

Sherwood, R. T. 1970. Physiology of Rhizoctonia solani. Pages 69-92 in: Rhizoctonia solani: Biology and Pathology. J. R. Parmeter, Jr., ed. University of California Press, Berkeley.

Thomashow, L. S., and Weller, D. M. 1988. Role of a phenazine antibiotic from Pseudomonas fluorescens in biological control of Gaeumannomyces graminis var. tritici. J. Bacteriol. 170:3499-3508.

Thomashow, L. S., Weller, D. M., Bonsall, R. F., and Pierson, L. S. 1990. Production of the antibiotic phenazine-1-carboxylic acid by fluorescent Pseudomonas species in the rhizosphere of wheat. Appl. Environ. Microbiol. 56:908-912.

Wang, H. H., and Schaffner, D. W. 2011. Antibiotic resistance: How much do we know and where do we go from here? Appl. Environ. Microbiol. 77:7093-7095.

Weller, D. M. 1988. Biological control of soilborne plant pathogens in the rhizosphere with bacteria. Annu. Rev. Phytopathol. 26:379-407.

Weller, D. M. 2007. Pseudomonas biocontrol agents of soilborne pathogens: Looking back over 30 years. Phytopathology 97:250-256.

Weller, D. M., Cook, R. J., MacNish, G. C., Bassett, E. N., Powelson, R. L., and Peterson, R. R. 1986. Rhizoctonia root rot of small grains favored by reduced tillage in the Pacific Northwest. Plant Dis. 70:70-73.

Weller, D. M., Landa, B. B., Mavrodi, O. V., Schroeder, K. L., De La Fuente, L., Blouin Bankhead, S., Allende Molar, R., Bonsall, R. F., Mavrodi, D. V., and Thomashow, L. S. 2007. Role of 2,4-diacetylphloroglucinol-producing fluorescent Pseudomonas spp. in the defense of plant roots. Plant Biol. 9:4-20.

Yang, M.-M., Mavrodi, D. V., Mavrodi, O. V., Bonsall, R. F., Parejko, J. A., Paulitz, T. C., Thomashow, L. S., Yang, H.-T., Weller, D. M., and Guo, J.-H. 2011. Biological control of take-all by fluorescent Pseudomonas spp. from Chinese wheat fields. Phytopathology 101:1481-1491.

Yin, C., Hulbert, S. H., Schroeder, K. L., Mavrodi, O., Mavrodi, D., Dhingra, A., Schillinger, W. F., and Paulitz, T. C. 2013. Role of bacterial communities in the natural suppression of Rhizoctonia solani bare patch disease of wheat (Triticum aestivum L.). Appl. Environ. Microbiol. 79: 7428-7438 